\begin{tabular}{|c|c|c|}
\hline $\begin{array}{l}\text { FATIH } \\
\text { SULTAN } \\
\text { MEHMET } \\
\text { VAKK UNIIVERSIESI } \\
2010\end{array}$ & $\begin{array}{l}\text { FSM İlmî Araştırmalar Insan ve Toplum Bilimleri Dergisi } \\
\text { FSM Scholarly Studies Journal of Humanities and Social Sciences } \\
\text { Sayı/Number } 15 \text { Yıl/Year } 2020 \text { Bahar/Spring } \\
\text { (C2020 Fatih Sultan Mehmet Vakıf Üniversitesi }\end{array}$ & 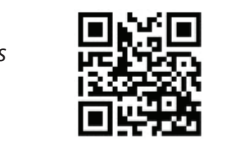 \\
\hline DOI: & http://dergipark.org.tr/fsmia & http://dergi.fsm.edu.tr \\
\hline Araştırma Makalesi / Research Article & Geliş Tarihi / Received: 26.04.2020 Kabul Tarihi / Accepted: 01.06.2020 & FSMIAD, 2020; (15): 401-430 \\
\hline
\end{tabular}

\title{
Sınırların Gölgesinde Göç: “Daha” Filmi Bağlamında Göçmen Kaçakçılığı Üzerine Sosyolojik Bir İnceleme
}

Kerem Özbey*

\section{Öz}

Bu çalışmada, Türkiye'deki Suriyelilerin Avrupa'ya göç deneyimlerine göçmen kaçakçılığı üzerinden odaklanılmaktadır. Göçmen kaçakçılarının ve kaçak göçmenlerin nasıl bir toplumsal profile sahip olduğu, Türkiye'nin sınır bölgelerinde kaçak göçler için ne tür bir mekânsal kurgunun oluşturulduğu, göçmen kaçakçılarının kaçak göçmenlere bakış açısının ne yönde olduğu, göçmen kaçakçılığının nasıl bir değişmeyen yüzü ortaya çıkardığı, göçmen kaçakçılığının kendi içinde nasıl bir iktidar mücadelesi, direniş ve yeniden tahakkümü barındırdığı ve göçmen kimliğinin anlaşılmasında sembollerin ve toplumsal hafıza mekânlarının nasıl bir rol ve işleve sahip olduğu, bu çalışmanın temel sorunsalını oluşturmaktadır. Çalışmada, "Daha" filmi üzerinden göçmen kaçakçılığı sosyolojik açıdan incelenmiş ve bu inceleme sonucunda birtakım sonuçlara ulaşılmıştır. Göçmen kaçakçılarının kaçak göçmenler üzerinden para kazanan ve onlara şiddet uygulayan, kadınlara tecavüz eden, onları fuhuşa sürükleyen, hastaları ve çocukları ölüme terk eden kişiler olduğu anlaşılmıştır. Türkiye'nin sınır bölgesinde Kandalı olarak bilinen bir mekânın kurgulandığı, bu mekânda kaçak göçmenlerin depoya hapsedildiği ve onlara her türlü insan onuruyla örtüşmeyen muameleler yapıldığı tespit edilmiştir. Kaçak göçmen-

Dr. Öğr. Üyesi, Artvin Çoruh Üniversitesi Fen-Edebiyat Fakültesi Sosyoloji Bölümü, Artvin/

Türkiye, ozbey-kerem@hotmail.com, orcid.org/0000-0001-8824-359X 
lerin kaldıkları deponun duvarlarına çeşitli sembolleri kazıdıkları, bu sembollerin depoyu bir toplumsal hafıza mekânına dönüştürdüğü ve göçmenlerin umutlarını, arzularını, dileklerini, beklentilerini, özgürlüklerini, kurtuluşlarını temsil ettiği sonucuna ulaşılmıştır. Neticede, kaçak göçmenlerin yaşadıkları sorunlara rağmen hedef ülkeye varmak için mücadelelerini sürdürdükleri anlaşılmıştır.

Anahtar Kelimeler: Sınır, göç, göçmen kaçakçılığı, Daha Filmi, Kandalı.

\title{
Migration under in the Shadow of Borders: A Sociological Study on Migrant Smuggling within the Context of the Film "Daha"
}

\begin{abstract}
This study focuses on the migration experiences of Syrians in Turkey to Europe through migrant smuggling. A social profile of migrant smugglers and illegal immigrants have created what kind of spatial organization in the border regions of Turkey for illegal immigration, immigrant smugglers, illegal immigrants viewpoints in the direction of an invariant face uncovered smuggling of migrants, migrant smuggling and how a power struggle, resistance and re-host the spaces of domination and immigrant identity and collective memory in the understanding of the role and function of symbols that constitutes the main problem of this study. In the study, migrant smuggling was examined sociologically through the movie "Daha" and some results were obtained as a result of this examination. Migrant traffickers were understood to be people who made money off illegal immigrants and used violence on them, raping women, driving them into prostitution, leaving patients and children to die. It was established that a place known as Kandali was built in the border region of Turkey, where illegal immigrants were imprisoned in warehouses and treated without any kind of human dignity. It is concluded that illegal immigrants engrave various symbols on the walls of the warehouse where they stay, these symbols transform the warehouse into a social memory space and represent the hopes, desires, wishes, expectations, freedoms and liberations of immigrants. As a result, it is understood that illegal immigrants continue their struggle to reach the target country despite their problems.
\end{abstract}

Keywords: Border, migration, migrant smuggling, Daha Film, Kandalı. 


\section{Giriş}

Günümüz gelişmeleri 1şığında Türkiye'nin temel sorunlarından biri ve belki de en önemlisi kuşkusuz göçtür. Göçün hızlanması, büyümesi, çeşitlenmesi ve küreselleşmesi gibi gelişmeler, Türkiye'nin yakın dönemde karşılaştığı sorunlar içerisinde göçü daha fazla ön plana çıkarmıştır. Göç türlerinin ve nedenlerinin bütün yönleriyle karşılığını bulduğu Türkiye'de yeni göç hareketleri içerisinde yer alan düzensiz (yasadış1/kayıtdış1/kaçak) göçler farklı boyutlar içermektedir. Ortadoğu'da artan siyasal karışıklıklar, iç çatışmalar, rejim değişiklikleri, otoriter rejimler ve savaşlar, kitlesel ve zorunlu göç hareketlerini artırmış, sayıları milyonlarla ifade edilen insanlar bulundukları ülkeleri terk etmek durumunda kalmışlardır. Suriye'de 2011 yılından bu yana devam eden savaş ortamı nedeniyle milyonlarca Suriyeli göç etmek zorunda kalmış, Türkiye gibi sınırdaş ülkeler başta olmak üzere çok sayıda ülkeye Suriyelilerin göçleri yaşanmıştır. Türkiye'nin Suriyeli göç deneyimi, çoğu ülkeden farklılık göstermektedir. Çünkü yaklaşık 4 milyon Suriyelinin göç ettiği Türkiye, diğer ülkelerle karş1laştırıldığında en fazla Suriyeli göçmeni içinde barındıran ülke konumundadır. Türkiye'deki Suriyelilerin önemli bir kısmının temel amacı Türkiye üzerinden Avrupa'ya göç etmektir. Bu göç isteği yasal bir zeminde karşılık bulamadığı için yasadışı yollardan yapılan göçlerin sayısında önemli artışlar gözlenmiştir. Türkiye'de yasadışı göçlerin artışı, kaçınılmaz bir biçimde göçmen kaçakçılığını ortaya çıkarmıştır.

Göçmen kaçakçılığını ortaya çıkaran ana gelişmeler, göç edecek insan sayısının hızla artması ve göç karşıtı kanun ve uygulamaların yaygın çeşitlilikte olmasıdır. Bu uygulamalar karşısında göçmenler, kaçak yollarla göç hareketlerini sürdürme eğilimi göstermektedir. Göçmen kaçakçıllğı, göçmenlerin sözü edilen eğilimlerinin bir sonucu olarak ortaya çıkmıştır. Türkiye, göçmen kaçakçılığının merkezindeki ülkelerin başında gelmektedir. Çünkü Türkiye, bir tarafı yoksulluk, işsizlik, geçimsizlik gibi kötü ekonomik koşulların, savaşların, iç çatışmaların, siyasal karışıklıkların ve rejim değişikliklerinin yaşandığı geri kalmış ülkeler ile diğer tarafı sosyal, ekonomik ve kültürel açılardan gelişmiş Avrupa ülkelerinin yer aldığı bir coğrafi bağlamda yer aldığ 1 için, geri kalmış ülkelerden gelişmiş ülkelere doğru göç akımlarının güzergâhı üzerinde yer almakta ve bu nedenle söz konusu göçlerle doğrudan muhatap konumundadır. Türkiye'nin transit göçler açısından bir geçiş bölgesi özelliklerine sahip olması, göçmen kaçakçılığı açısından Türkiye'yi daha önemli hale getirmiştir. Türkiye, düzensiz göçlerin, daha özelde göçmen kaçakçılığının yoğun olarak görüldüğü bir ülke olarak çok sayıda göçmen açısından öncelikli bir konuma sahiptir. 
Türkiye'deki Suriyelilerin önemli bir kısmı yasadışı yollarla önce Yunanistan'a daha sonra da Avrupa ülkelerine göç etmeyi hedeflemiştir. Bu durum kaçak göçleri ortaya çıkarmış, çok sayıda Suriyeli göçmen Yunanistan'a deniz yoluyla gitmek isterken yolda yaşamını yitirmiştir ancak yine de kaçak yollardan geçişler devam etmiştir. Kaçak göç olayı kendisine özgü bir sektör oluşturmuş, bu sektörün çok sayıda kaçak çalışanı oluşmuştur. Özellikle göçmen kaçakçıları bu sektörün belkemiğini oluşturur hale gelmiştir. Bu bağlamda, Türkiye üzerinden Avrupa'ya göç etmeyi hedefleyen Suriyeli göçmenlerin karşılaştıkları en önemli engellerden biri sınırlardır. Ulus-devletler, sınırlar vasıtasıyla artan göç akımlarını engellemeyi, denetlemeyi ya da düzenlemeyi amaçlamaktadır. $\mathrm{Bu}$ amaç, uluslararası göç akımları bağlamında sınırları daha önemli hale getirmiştir.

Günümüzde göçlerin bilhassa da düzensiz göçlerin küresel boyutlarda artış göstermesi, sınırların kaçak göçlerin cazibe merkezlerine dönüşmesi, göçmen kaçakçılığının giderek yaygınlaşması gibi gelişmeler, göçlerin karmaşık, çok boyutlu ve dinamik yapısını anlamayı kaçınılmaz kılmıştır. Göçlerin anlaşılmasında kuşkusuz sinema önemli bir tutmaktadır. Çünkü sinemanın göçü konu edinmesi sosyoloji açısından zengin bir kaynak oluşturmaktadır. Hayriye Erbaş'ın da vurguladığg gibi sinema göçü anlattığında, betimlediğinde sosyolog için çok sayıda örnek sunar. Öyle ki sinema filmlerinden kesitler, göç sosyolojisindeki kavram ve teorileri aktarırken tartışmaları verimli kılan bir araç olarak işlev görür. Yöntem, yaklaşım ve araçları oldukça farklı olan bu iki alan birbirinden beslenebildiği durumlarda sonuç, her iki alanın da zenginleşmesi biçiminde ortaya çıkar. ${ }^{1} \mathrm{Bu}$ açıdan göç konulu filmler, göç sosyolojisi için önemli temeller oluşturmaktadır. Göç sosyolojisiyle ilgili bu metinde göç konulu bir filme başvurulmasının temel sebebi, günümüz göçlerinin içerdiği sorunların filmlere nasıl yansıdığını, filmler aracıllğ̆ıyla ne şekilde ele alındığını ve göç kuramlarıyla göç konulu filmler arasında nasıl bir ilişkiselliğin olduğunu ortaya çıkarmaktır. Filmin, göç sosyolojisiyle ilgili temel çıkış noktası olması, esasında filmler de dahil tüm sanatsal ürünlerin toplumsal gerçeklikten bağımsız olmadığına işaret etmektedir. Diğer bir ifadeyle, sanat, toplumsal ve kültürel bir üretimdir ve içinde bulunduğu toplumsal gerçeklikten hareketle oluşturulur. Bu bakımdan bir sanatsal etkinlik olan filmler, toplumsal gerçekliğe ilişkin bir perspektif içermekte, onu izleyenlerin zihninde toplumsal gerçekliği yeniden inşa etmekte ve bu anlamda toplumsal gerçekliği resmetmeye yarayan bir görsellik sunmaktadır. Bu anlamda göç konulu filmler, sosyal bilimsel bir araştırma olan bu çalışmanın temel dayanaklarından birini oluşturmaktadır.

1 Hayriye Erbaş, Göç ve Göçmenler: Kuram, Yöntem ve Alan Yazıları, Ankara, Phoenix Yayınlar1, 2019, s. 26-27. 
Göçmen kaçakçıları ve kaçak göçmenler nasıl bir toplumsal profile sahiptir? Türkiye'nin sınır bölgeleri kaçak göçler için ne tür bir mekânsal kurguyu içermektedir? Göçmen kaçakçılarının kaçak göçmenlere bakış açısı ne yöndedir? Göçmen kaçakçılı̆̆ 1 nasıl bir değişmeyen yüzü ortaya çıkarmıştır? Göçmen kaçakçıllı̆̆ kendi içinde nasıl bir iktidar mücadelesi, direniş ve yeniden tahakkümü barındırmaktadır? Göçmen kimliğinin anlaşılmasında sembollerin ve toplumsal hafıza mekânlarının nasıl bir rol ve işlevi bulunmaktadır? Bu sorular, bu çalışmanın temel sorunsalını oluşturmaktadır. Bu sorunsal bağlamında, çalışmanın temel amac1, göç konulu bir film aracılı̆̆ıyla yasadışı göçleri, göçmen kaçakçı1ığını, sınırların yasadışı göçler üzerindeki etkilerini ve Türkiye'deki Suriyelilerin kaçak göç deneyimlerini anlamaktır. Bu bağlamda, çalışmada, yönetmenliğini Onur Saylak'ın yaptığı, Hakan Günday'ın 2013 yılında aynı adla yayınlanan romanından uyarlanmış 2017 yılı yapımı "Daha” filmi ele alınmıştır. Film, göçmen kaçakçısı bir baba ile oğlu arasındaki çatışmayı, daha sonra oğulun karşı çıtı̆̆g babasına dönüşme sürecini, Suriyeli göçmenlerin kaçak göç süreçlerinde karşılaştıkları sorunları, yaşadıkları dramları ve verdikleri mücadelenin maddi, sembolik ve toplumsal görünümlerini konu edinmektedir. Göçmen kaçakçılarının örgütlenme ve işbölümünü, çalışma ve yaşam koşullarını, iş ilişkilerini, göçmenlere davranış biçimlerini, aile içi ilişkilerini, göçmenler üzerinden kurulan iktidar pratiklerini, farklı türde şiddet olaylarını, tecavüz, fuhuş, ölüm gibi birbirinden farklı temaları konu edinen film, bu yönleriyle Türkiye'nin göç deneyimine 1şı tutmaktadır. Sözü edilen filmin düzensiz göçlerle ilgili sosyolojik bir analize imkan tanımasının temel sebebi, filmde işlenen temaların gündelik yaşam pratikleri içerisinde yer alması, toplumsal gerçekliğe ilişkin somut veriler içermesi ve Türkiye'nin son dönem göç merkezli sorunlarını doğrudan yansıtmasıdır.

\section{Göçmen Kaçakçılarının ve Kaçak Göçmenlerin Toplumsal Profili}

Düzensiz göç tanımı, mevcut kurum ve kurallara uygun olmadan gerçekleşen göç hareketlerini; düzensiz göçmen ise herhangi bir ülkede yabancılarla ilgili düzenlemelere uygun olmayan kişileri tanımlamaktadır. ${ }^{2}$ Sınırın insan hareketini mekânsal ve zamansal olarak kısıtladığı ve bu kısıtlamanın aşıldığı noktada düzensiz göç kavramı doğmaktadır. ${ }^{3}$ Düzensiz göçlerin bir sonucu olarak ortaya çıkan göçmen kaçakçılığı, dolaylı veya doğrudan mali veya maddi

2 Sema Erder, İstanbul Bir Kervansaray (mı?): Göç Yazıları, der. Nesrin Uçarlar, İstanbul, İstanbul Bilgi Üniversitesi Yayınları, 2015, s. 78.

3 Reyhan Atasü-Topçuoğlu, "Düzensiz Göç: Küreselleşmede Kısıtlanan İnsan Hareketliliği", Küreselleşme Çağında Göç: Kavramlar, Tartışmalar, der. S. Gülfer Ihlamur-Öner, N. Aslı Şirin-Öner, İstanbul, İletişim Yayınları, 2012, s. 501-502. 
çıkar sağlamak üzere bir kişinin vatandaşı olmadığı bir ülkeye yasadışı girişini sağlamaktır. Yasadışı giriş sınırların yasal gerekliliklere uymadan geçilmesi anlamını taşımaktadır. ${ }^{4}$ Hemen bütün ülkelerdeki ulusal kurumlar, düzensiz göçü yasadışı bir olgu olarak kabul etmekte ve göçmenler sadece göç ettikleri için suçlu konumuna düşebilmektedir. Bu durumdaki göçmenler, siyasal göçmenlere göre çok daha zor ve korunmasız durumdadır ve gittikleri ülkelerdeki bütün kötü koşullara razı olmaktadırlar. ${ }^{5}$ Üçüncü bir kanal aracılığıyla yasadışı olarak sınır geçmek ${ }^{6}$ ve maddi kazanç elde etmek için yasadışı yollardan göçmenleri başka bir ülkeye geçiren göçmen (insan) kaçakçılar. ${ }^{7}$ filmde, kamyoncu ve tekneci mesleklerine sahip, kültürel açıdan alt kültür gruplarından gelen ve bu anlamda geleneksel ve ataerkil kodlara sahip olan, sınıfsal olarak alt sinifa mensup kişilerden oluşmaktadır. Bu nedenle para kazanmak isteyen göçmen kaçakçıları, göçmenleri ekonomik sermayeleri açısından bir kaynak ve sınırları da birer kazanç kapısı olarak görmektedir. Kaçak göçmenler ise filmde, evsiz ve vatansız bir kimliğe sahip ve Avrupa'ya gitmek için göçmen kaçakçılarının uygulamalarından olumsuz etkilenen kimseler olarak görülmektedir. Stephen Castles ve Mark J. Miller'a göre, bazı durumlarda, iyi iş ve ücret vaatleri karşısında, göçmenler insan kaçakçılarının aracılığını kabul etmektedirler. ${ }^{8}$ Ahmet İçduygu'ya göre ise, kaçakçıları kabul edenler daha çok Türkiye'yi bir geçiş ülkesi olarak görüp, Batıya göç etmek isteyen transit göçmenlerdir. Yapılan görüşmeler, Türkiye'ye sınırı bulunan ülkelerden gelen yabancı göçmenlerin kaçakçıları daha çok kabul ettiklerini göstermiştir. ${ }^{9}$ Göçmen kaçakçıları ile kaçak göçmenlerin birbirlerini kabul etme biçimlerini ve kaçak göçmenlerin kaçak yollardan nasıl Avrupa'ya göç ettiklerini filmdeki karakterler üzerinden anlamak mümkündür.

Filmdeki Ahad karakteri, Suriyeli göçmenleri kaçak yollarla Türkiye'ye getiren ve yine kaçak yollarla Türkiye'den Yunanistan'a ve daha doğrusu Avru-

4 Gülay Toksöz, Uluslararası Emek Göçü, İstanbul, İstanbul Bilgi Üniversitesi Yayınları, 2006, s. 110 .

5 Sema Erder, "Yabancısız Kurgulanan Ülkenin Yabancıları”, Türkiye'de Yabancı Iş̧̧̧iler: Uluslararası Göç, İsgücü ve Nüfus Hareketleri, der. F. Aylan Arı, İstanbul, Derin Yayınları, 2007, s. 35 .

6 Ahmet İçduygu, Türkiye'de Kaçak Göç, İstanbul, İstanbul Ticaret Odası Yayınları, 2004, s. 24.

7 Yusuf Adıgüzel, Göç Sosyolojisi, Ankara, Nobel Akademi Yayınları, 2016, s. 113.

8 Stephen Castles, Mark J. Miller, Göçler Çağı: Modern Dünyada Uluslararası Göç Hareketleri, çev. Bülent Uğur Bal, İbrahim Akbulut, İstanbul, İstanbul Bilgi Üniversitesi Yayınları, 2008, s. 165.

9 Ahmet İçduygu, a.g.e., s. 24. 
pa'ya taşıyan aracı biridir. Kaçak göçmenleri kamyonunun kasasına doldurup yaşadığı evin deposuna taşıyan Ahad, oradan da uygun zamanı kollayıp teknelerle Yunanistan'a göndermektedir. Bir tür aracı pozisyonunda olan Ahad, filmde, göçmenleri kaçak yollarla Avrupa'ya gönderen biri olmasının yanında aynı zamanda bu göçmenler üzerinden para kazanan, bu süreçte göçmenlere şiddet uygulayan, göçmen kadınlara tecavüz eden ve o kadınları para karşılığında fuhuşa sürükleyen biri olarak karşımıza çıkmaktadır. Ekonomik doyumsuzluğu nedeniyle Ahad, göçmenleri insan onuruna yakışmayan şartlara sürüklemekte ve onları her türlü sömürüye açık hale getirmektedir. Göçmenlerin sadece yemek, barınak, tuvalet gibi geçici temel ihtiyaçlarını oldukça kısıtlı bir biçimde karşılayan Ahad, onları bir an önce teknelerle göndermenin sabırsızlığı içindedir. Çünkü ne kadar göçmeni kaçak bir biçimde sınırın öteki tarafına gönderirse o kadar para kazanacak olan Ahad, filmdeki teknecilerle bu konuda sürekli tartışmış ve filmdeki ölümü diğer kaçakçılarla olan anlaşmazlığına bağlı bir şekilde gerçekleşmiştir. Ahad'ın yanı sıra filmdeki diğer iki göçmen kaçakçısının yaptıkları iş, teknelerle göçmenleri kaçak yollarla sınırı geçirmektir. Ahad'tan göçmenleri teslim alıp Yunanistan'a gönderen bu iki göçmen kaçakçısı ise filmde Ahad kadar ön planda yer almasa da Ahad'la benzer toplumsal profile sahip kişilerdir.

Ahad'la birlikte filmdeki diğer baş aktör konumunda olan kişi, Ahad'ın oğlu olan Gaza'dır. 14 yaşında olan Gaza, hayallerinin ve ideallerinin peşinde bir kimliğe sahip biridir. Gaza, bulunduğu yerden ayrılıp büyük şehre gitmeyi, öğrenimini orada sürdürmeyi ve oradaki sosyal çevreye dâhil olmayı planlarken, babas1 onu hayallerinin ve ideallerinin çok ötesindeki bir dünyayla tanıştırmaktadır. Babası Gaza'yı göçmen kaçakçıllğının olduğu ilişkiler ağına dâhil etmekte ve onu tıpkı kendisi gibi biri olarak yetiştirmeyi amaçlamaktadır. Bu amaç doğrultusunda Gaza'ya göçmen kaçakçılığı işinin nasıl yapıldığını öğreten babası, aynı zamanda yaptığ 1 işi öğrenmesi için Gaza'ya baskı ve şiddet uygulamaktadır. Tek gayesinin babası ve parası olması gerektiğini Gaza'ya dikte eden Ahad, ona sürekli görev ve sorumluluklar yüklemiş ve göçmen kaçakçılığını içselleştirmesini ve kaçak göçmenlerle sürekli temas kurması yoluyla bu işi yapması için baskıyı daha da artırmıştır (Bkz. Resim-1). Ancak Gaza, babasının tahakkümüne karşılık, sürekli bir çıkış yolu aramaktadır. Bir taraftan sınavlara girip başarı elde ederken, diğer taraftan da göçmen kadına âşık olan Gaza, filmde bir kimlik bunalımının içerisinde yer almaktadır. Bu bunalımdan kurtulmak için çok çabalasa da Gaza, filmin sonunda babası gibi hatta ondan daha ileri boyutlarda bir göçmen kaçakçısına dönüşmektedir. 


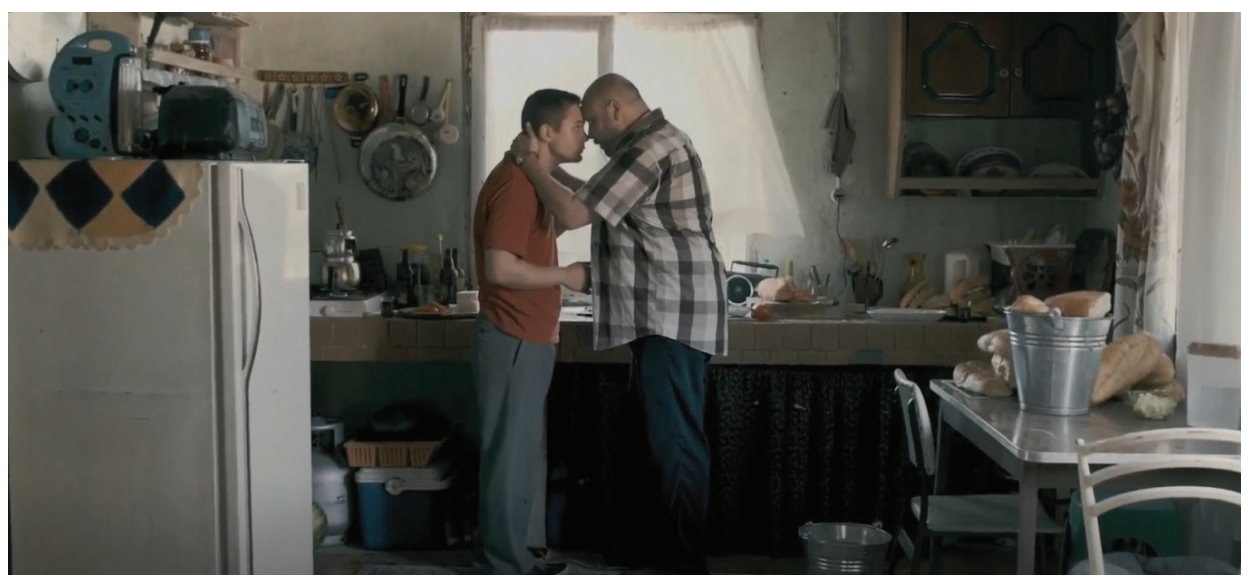

Resim-1: Ahad'ın Gaza'yı baskı yoluyla ikna etmesi

Filmdeki Ahad ve Gaza karakterlerinin yanında en önemli diğer karakterler, bizzat göçmenlerdir. Kaçak yollarla Yunanistan'a ve oradan diğer Avrupa ülkelerine gitmek üzere Türkiye'ye getirilen insanlardır göçmenler. Sınırların gölgesinde göç eden göçmenler için Türkiye, kaçak yollar içerisinde sadece geçilmeyi bekleyen sınırlar arasındaki bir güzergâhtır. Göçmenler açısından sınırlar, bir güzergâhın son buluşu ve yeni güzergâhın başlangıcını ifade etmektedir. Göçmenler açısından her sınır yeni bir umut kapısıdır, her sınır geçişi de umuda açılan yeni bir kapı niteliğindedir. Filmde göçmenlerin umuda yolculuğu, göçmen kaçakçılarının göçmenleri kamyonların kasalarına tıka basa doldurması, evlerinin depolarına hapsetmesi ve teknelere hiç boş yer kalmayacak şekilde bindirmesi şeklinde gerçekleştirilmiştir. Bülent Çiçekli ve Oğuzhan Ömer Demir'in belirttikleri gibi, yolculuklarda ülkeler içinde geçişler çoğunlukla kapalı kısa kamyon, kamyonet, otobüs ya da minibüslerle gerçekleştirilmekte, bu seyahatlerde de yine çok sayida yasadışı göçmen bir arada bulunmaktadır. Göçmenlerin büyük bir kısmı bu yolculuktan ve olumsuz şartlarından şikayet etmemektedir. Her nasılsa hedef alınan yere gitmek için bu tür sıkıntılara katlanmak gerektiğini belirten göçmenler, süreci sorunsuz atlatmak için çoğu zaman kaçakçıların vermiş olduğu rahatsızlık, kötü muamele ve eziyetlere katlanmayı tercih etmektedirler. ${ }^{10}$ Göçmen kaçakç1larının vicdansız ve merhametsiz uygulamalarına maruz kalan göçmenler, çıktıkları zorlu yollarda şiddete, tecavüze ve fuhuşa uğrayan ve ölüme terk edilen kişilerdir. İnsan onuruyla örtüşmeyen muamelelerle karşılaşan göçmenler, her ne pahasına olursa olsun, hedeflerinden vazgeçmemektedirler. Göçmenler kaçak, sa-

10 Bülent Çiçekli, Oğuzhan Ömer Demir, Türkiye Koridorunda Yasadışı Göçmenler, Ankara, Karınca Yayınları, 2013, s. 124. 
vunmasız ve yersiz-yurtsuz olmaları nedeniyle her tür kapitalist sömürünün kurbanı haline gelmektedirler. Göçmenlerin sınırlar arasında kalan durumlarını Iain Chambers şu şekilde anlatıyor: "Sınırların olduğu her yerde bu sınırların ötesinde başka sesler, başka bedenler ve başka dünyalar olduğunu kavramaya başliyorum. Arzularımın peşinde böylesi sınırları aşarken, çelişkili bir biçimde hem bizzat beni hapseden sınırlarla hem de sınırlarımı aşan bir diyaloğu sürdürme arayışındaki bir taşkınlıkla yüzleşmek zorunda kalıyorum. Öyle ya da böyle bu sınır ülkesine düşmüş birisi olarak hep daha ötede potansiyel bir yeri arıyor gözlerim: başka bir yer, başka bir dünya, başka bir gelecek ihtimali." ${ }^{11}$ Kaçak göçmenlerin sınır deneyimleri de Chambers'in belirttiği şekilde gerçekleşmektedir. Filmde de görüldüğü üzere, her sınır kaçak göçmenler için bir engel olabildiği gibi, aynı zamanda yeni bir başlangıç, yeni bir dünya ve yepyeni bir gelecek imgesini içermektedir.

Göç kuramları arasında yer alan yeni ekonomi kuramına göre, göç etme kararı tek tek bireyler tarafından değil, bir hane halkının tüm fertleri hatta bazen topluluğun tümü gibi birbiri ile ilintili çok sayıda kişi tarafından alınmaktadır. $\mathrm{Bu}$ şekilde alınan kararlar, sadece beklenen gelirin en üst düzeye çıkarılmasında rol oynamamakta, aynı zamanda gelirle ilgili rizikoların azaltılması ve yerel piyasaların başarısızlıkları aşmasında da etkin olmaktadır. ${ }^{12}$ Bu kuramsal yaklaşım açısından bakıldığında, filmdeki kaçak göçmenlerin göçe tek tek bireyler şeklinde değil, daha ziyade hane halkının tüm üyelerince katıldıkları anlaşılmaktadır. Aileler halinde göç etme eğilimi çok sık görüldüğü için yeni ekonomi kuramının parametrelerini burada görmek mümkündür.

\section{Kandalı: Türkiye'nin Sınır Bölgelerindeki Yeni Kurgusal Mekânı}

Sınır kendinden önce var olmayan iki taraf yaratır. İki ülke, iki ev, iki insan arasında bir yeri iç, bir yeri dış ilan ederek bir gerilim oluşturur. İçindekileri dışarıdan koruyabildiği gibi hapsediyor da olabilir. Benzer şekilde dışardakileri içerdekilerden koruyor ya da onları dışlıyor olabilir. Her durumda sınır, iletişim ve üretim ihtimalini ortadan kaldıran ve müdahale kabul etmeyen yani değişmeyeceği varsayılmış katı ve ölü tanımların ürünüdür. ${ }^{13} \mathrm{Bu}$ bağlamda sınırlar, ülkeleri bölen ve birleştiren, göçmenler tarafindan geçilen ve devletler tarafindan göçmenleri uzak tutmak için çeşitli şekillerdeki bariyerlerce kuvvetlendirilen

11 Iain Chambers, Göç, Kültür, Kimlik, çev. İsmail Türkmen, Mehmet Beşikçi, İstanbul, Ayrıntı Yayınlar1, 2014, s. 18.

12 Nermin Abadan-Unat, Bitmeyen Göç: Konuk Işşilikten Ulus-ötesi Yurttaşlığa, İstanbul, İstanbul Bilgi Üniversitesi Yayınları, 2006, s. 24.

13 Serazer Pekerman, Film Dilinde Mahrem: Ulusötesi Sinemada Kadın ve Mekân Temsili, İstanbul, Metis Yayınları, 2012, s. 189. 
coğrafi ve politik hatlardır. Bununla beraber ulus-devletin coğrafyası göç için önemli içeriksel faktördür ve devletlerarası sınırlar göç hareketini tanımlamakta yardımcıdır. Sınırlar sadece geçiş veya ayırıcılık noktaları değildir, aynı zamanda belirlediği alanların ayrımları göçü sonlandıran eylemlerdir. ${ }^{14}$

Filmin geçtiği yer, "Kandalı” olarak belirtilen hayali bir sınır mekânıdır. Bu mekân Türkiye'nin sınır bölgelerinde kaçak göçmenlerin yer aldığ 1 bir alanda kurgulanmıştır. Göçmen kaçakçılığının geçiş güzergâhı üzerinde yer alan Kandalı, esasında göçmen kaçakçıları tarafından kurgulanan bir sınır mekândır. Ancak bu sınır mekânıyla ilgili filmde izleyicilere bir subliminal mesaj verilmektedir. Dikkatli bir şekilde bakıldığında, filmde göçmen kaçakçısı rolünde yer alan Ahad'ın göçmenleri taşımak için kullandığı kamyonetin plakası 82 ile başlamaktadır. Bilindiği üzere Türkiye'de araç plakaları en son Düzce kentinin plakası olan 81 ile son bulduğu halde, filmde, kamyonun, sanayideki otomobilin ve teknecilerin kullandığı motosikletlerin plakalarının 82 olması, Kandalı'nın Türkiye'nin yeni kentsel mekânı olarak kurgulandığına işaret etmektedir. Bu kentsel mekânın kaçak göçmenlerden oluştuğu ve genellikle de sınır bölgelerinde kurulduğu ifade edilmektedir. Kandalı, kaçak göçmenler açısından bir ara geçiş güzergâhı gibi düşünülse de, esasında kaçak göçmenlerin hiç eksik olmadığı bir mekândır. Mevcut olanlar sınırdan geçirilip Yunanistan'a gönderilirken, yeni gelenler hiç boşluk bırakmadan Kandalı'ya yerleştirilmektedir. Kandalı, gideni ve geleni hiç eksik olmayan bir kaçak göçmen kenti halini almıştır. Filmin başrol karakteri konumunda olan Ahad açısından Kandalı, bir sermaye mekânıdır. Bu mekânda para kazanmak için her şey meşru kabul edilmektedir. İnsan ticaretinden fuhuşa, tecavüzden gece hayatına kadar uzanan geniş bir yelpazede Kandalı, Yunanistan'a ve oradan da diğer Avrupa ülkelerine gitmek üzere Türkiye'ye kaçak yollardan getirilen Suriyelilerin göçmen kaçakçılarının tasarrufuna terk edildiği, depolara hapsedildiği, insan onurunun yok sayıldığı koşulların olduğu bir mekânsal birimi ifade etmektedir. Filmde bir sınır mekânı olarak kurgulanan Kandalı, kaçak göçlerin mekânını sembolize etmektedir. Bu mekânda yer alan depo, göçmen kaçakçısı Ahad için para kazanmanın merkezi olarak görülmektedir. Her gelen göçmen kafilesi, Ahad için yeni bir kazanç demektir ve depo bir kazanç kapısını sembolize etmektedir. Dahası, Ahad için Kandalı ve evinin deposu, göçmenlere her türlü şiddeti reva gördügüu, göçmen kadınlara tecavüz ettiği, onları para karşılığında fuhuşa sürüklediği ve çocukları ölüme terk ettiği mekânın adıdır. Bu mekânın içerdiği anlamlar ve izleyicinin hafızasında bıraktığı izler, göçmen

14 David Bartram, Maritsa V. Poros, Pierre Monforte, Göç Meselesinde Temel Kavramlar, çev. Itır Ağabetoğlu Tuncay, Ankara, Hece Yayınları, 2017, s. 47. 
kaçakçılığının değişmeyen yüzünü oluşturmaktadır. Kandalı'nın ve Kandalı' daki evin deposunun Gaza için ise anlamı farklıdır. Başlangıçta Gaza için Kandalı, babası gibi olmanın, ona destek olmanın, onun yaptıklarını yapmanın, yapmadıklarını da yapmamanın ve babasının yaptıkları kötülüklere çanak tutmanın mekânı olmuştur. Daha sonra aynı Kandalı, Gaza için kurtulması gereken bir hapishaneye dönüşmüş, Gaza'nın özgürlügünü, ideallerini ve hayallerini engelleyen bir mekân halini almıştır. Özellikle Kandalı' daki evin deposunda Gaza, sadece babasının insani olmayan uygulamalarına tanıklık etmemiş, aynı zamanda bu uygulamalara da bizzat destek vermiştir. Bununla birlikte Kandalı, Gaza'nın bütün kötülüklere kayıtsız kalamadığı, babasının yapıp ettiklerine katlandığı ve kaçıp kurtulmak için gün saydığı bir mekândır. Bu bağlamda, babasının izinden gittiği, onu taklit ettiği, onun gibi olmak istediği zamanlar, Gaza'nın depoyu hapishane kendisini de bu hapishanenin gardiyanı olarak gördüğü zamanlar olmuştur. Ancak babasının otoritesini sorguladığ1, ondan kurtulmaya çalıştığ1 ve ondan şiddet gördüğü zamanlar ise, Gaza'nın depoyu hapishane, kendisini de bu hapishanenin mahkûmu olarak gördüğü zamanları ifade etmiştir. Bu bakımdan Kandalı'daki evin deposu, farklı zamanlarda farklı anlamları içeren bir mekânı sembolize etmiştir.

Göçmenler, kaçakçılar nezaretinde yola devam ediyorlarsa, kaçakçılar tarafindan uygun görülen mekânlarda konaklamak durumunda kalmaktadırlar. Otel gibi ödeme gerektiren yerler nadiren kullanılmakta, kullanılması halinde ödemeler göçmenlerce yapılmaktadır. Bunun dişında çoğunlukla, ev, apartman daireleri, köy evleri veya ahır, samanlık gibi kapalı yerlerde tutulmaktadırlar. Bu esnada yabancıların minimum düzeyde gıda ihtiyaçları da kaçakçılar tarafından karşılanmakta, ekmek, su, bisküvi gibi besleyici olmasa da minimum düzeyde doyurucu olan gidalar tercih edilmektedir. ${ }^{15}$ Filmde, göçmenler, göçmen kaçakçısı Ahad ile oğlu Gaza tarafindan Kandalı'da yer alan evlerinin deposuna yerleştirilmişlerdir. Göçmen kaçakçıları depodaki kaçak göçmenlerin gıda ihtiyaçlarını karşılaşmış, onlara yarım ekmek arası domates, biber ve peynir vermişlerdir. Ahad'ın göçmenler için yemek hazırlığı yaparken parmaklarını yiyecekmiş gibi davranışlarda bulunması, esasında göçmenlere sunulan gıdaların onlar için ne kadar kıymetli olduğunu göstermektedir.

David Harvey'in mekân konusundaki yaklaşımı üzerinden filmdeki yeni kurgusal sınır mekânı olan Kandalı'yı anlamak mümkündür. Harvey'e göre mekân, ontolojik bir kategori değil, insanı biçimlendiren ve onun tarafindan biçimlendirilen toplumsal bir boyuta sahiptir. Mekânsal biçimler, içinde toplumsal süreçlerin oluştuğu cansız nesneler olarak değil, toplumsal süreçleri, bu süreçlerin 
mekânsal olmasıyla aynı tarzda içeren şeyler olarak görülmektedir. ${ }^{16}$ Harvey'in mekân kavramından bakıldığında, Kandalı'nın toplumsal açıdan biçimlendirilmiş, toplumsalı biçimlendiren, içerisinde toplumsal süreçlerin yer aldığ 1 bir mekân olduğu anlaşılmaktadır. Bir başka ifadeyle, Kandalı, göçmen kaçakçılar ve kaçak göçmenler tarafından biçimlendirilmiş, onları biçimlendiren ve sınırlar gölgesinde göç süreçlerinin yaşandığı bir mekândır. Konuya Henri Lefebvre'nin mekân kavramı açısından bakıldığında, Lefebvre'nin algılanan, tasarlanan ve yaşanan olarak bahsettiği üç tür mekân içerisinde Kandalı'nın ağırlıklı olarak tasarlanan mekânla örtüştüğü söylenebilir. Lefebvre'ye göre, "mekân temsilleri, yani tasarlanmış mekân; bilginlerin, planlamacıların, şehircilerin, parçalayan ve düzenleyen teknokratların, yaşananı ve algılananı tasarlananla özdeşleştiren, bilimselliğe yakın kimi sanatçıların mekânı. Bu, bir toplumun (bir üretim tarzının) içindeki egemen mekândır." ${ }^{17}$ Lefebvre mekân kavramı üzerinden bakıldığında, Kandalı, sınır, göç, kaçakçılık bağlamında tasarlanmış bir mekândır ve filmde yer alan göçmen kaçakçıları ile kaçak göçmenler, Kandalı'nın mekânsal yeniden üretiminde doğrudan önemli bir yer tutmuşlardır.

Göç kuramları arasında yer alan kesişen firsatlar kuramına göre, belli bir uzaklığa göç eden insanların sayısı, gittikleri yerdeki firsatların çokluğuyla orantılıdır. Yani, gidilecek yerde iş bulma firsatı fazla ise oraya göçecek insan sayısı da fazla olacaktır. ${ }^{18}$ Yine bu kurama göre göç için katedilecek mesafede, aşılacak olan ulus-devletlerin sınırları ve bu sınır geçişleri, göç üzerinde olumsuz bir etkide bulunmaktadır. Çünkü her aşılacak olan sınır, bir kontrol sistemi ve mekanizmasını da beraberinde getirmektedir. Bu durum da, uluslararası göçü oldukça zorlaştıran bir etken ve uluslararası göç için bir sınırlama anlamına gelmektedir. ${ }^{19}$ Bu kuram açısından bakıldığında, filmdeki kaçak göçmenlerin Avrupa'ya göçü ekonomik firsatların çokluğuyla doğru orantılıdır. Bu sebeple göç eden insan sayısı hayli fazladır. Bununla birlikte bu kurama göre, Kandalı, kaçak göçmenler açısından bir sınır mekânı olduğu için çeşitli olumsuzlukları içinde taşımakta ve sınırların neden olduğu kısıtlamalar nedeniyle göç sürecini zorlaştırmaktadır. Her sınır göçmenler için yeni bir mekânsal kısıtlama ve hedefe giden yoldaki bir engel olması sebebiyle olumsuz anlamları içermektedir. Sınırların gölgesinde yapılan kaçak göçler, her ne kadar göçmenler açısından çok sayıda engel ve risk taşısa da, esasında sınırların geçilmesi yeni firsatlar ve imkânlar penceresi olarak da

16 David Harvey, Sosyal Adalet ve Şehir, çev. Mehmet Moralı, İstanbul, Metis Yayınları, 2003, s. 11.

17 Henri Lefebvre, Mekânın Üretimi, çev. Işık Ergüden, İstanbul, Sel Yayınları, 2015, s. 68.

18 Cemal Yalçın, Göç Sosyolojisi, Ankara, Anı Yayınları, 2004, s. 28.

19 Savaş Çağlayan, "Göç Kuramları, Göç ve Göçmen İlişkisi”, Muğla Üniversitesi Sosyal Bilimler Enstitüsü Dergisi, 17, 2006, s. 77-78. 
görülmektedir. Bu bakımdan sınırlar, risk ve engeller kadar firsatlar ve imkânları da içeren sosyolojik yapılar olarak karşımıza çıkmaktadır.

\section{Göçmen Kaçakçılarının Bakış Açısından Kaçak Göçmenler}

İnsan ticareti ve kaçakçı1lığı, göçe olanak tanıyan yasadışı aktiviteleri simgelemektedir. Kaçakçılar, belgesiz göçmenlerin veya kaçak göçmenlerin sınırları geçmesine yardımcı olurken, insan ticareti yapanların eylemleri göçmenlere yapılan zorlama ve onları aldatmayı içermektedir. İnsan ticareti ve insan kaçakçılığ göçe yardım etmekten ve göçe zorlamaktan kâr sağlayan örgütlerin ve insanların aktivitelerini kapsamaktadır. ${ }^{20}$

Film, göçmen kaçakçılarının bakış açısından kaçak göçmenleri anlatmaktadır. Filmin başlangıcında vurgulanan temel mesaj şu olmuştur: "insanın kullandiğ ilk alet başka bir insandır”. Bu anlamda kaçak göçmenler, göçmen kaçakç1larının kullandıkları en temel aletlerin başında gelmektedir. Göçmen kaçakçıları açısından göçmenler belirli bir ücret karşıllğında kaçak yollarla sınırdan geçirilecek kişiler olarak görülmektedir. Burada göçmen kaçakçıllğı yapanlar, neyi ya da kimi taşıdıklarından ziyade ne kadara taşıdıklarını ve sınırdan geçişten kaç para alacaklarını önemsemektedirler. Ekonomi faktörü belirleyici olduğu için, göçmen kaçakçıları sınırdan geçirdikleri insanlara yeterince önem vermemektedirler. Öyle ki, filmde de görüldüğü üzere kaçak göçmenler kamyonun kasasına tıka basa doldurulup, adeta hayvan taşır gibi taşınmaktadırlar. Göçmen kaçakçıları ile kaçak göçmenler birbirlerinin dillerinden anlamadıkları için, göçmen kaçakçılarının sürekli yüksek ses tonuyla bağırarak göçmenlere emir verdikleri görülmektedir. Filmde Ahad göçmenleri kaçak yollarla evinin deposuna getirdikten sonra depoda göçmenlere şunları söylemektedir: "Bak, bu çocuk yemek getirecek yiyeceksin, su getirecek içeceksin, bu kovayı alacaksın buraya içine gireceksin hacet edeceksin, hacet. Burada sakin sakin bekleyeceksin. Zamanı gelince gideceksin. Tamam, anladın mı?" Göçmen kaçakçısı Ahad'ın ifadelerinden de anlaşılacağı üzere, göçmenler, esasında masrafsız kişiler olarak görülmektedir. Sadece yemek, su, tuvalet gibi ihtiyaçları karşılanması gereken kişiler olarak görülen göçmenlere bu yönleriyle bugün gelip yarın gidenler olarak bakılmaktadır.

Göçmen kaçakçısı Ahad'ın kaçak göçmenlerle ilgili olarak oğlu Gaza'ya yapmış olduğu konuşma, onun kaçak göçmenlere yönelik bakış açısını göstermektedir: "Görüyorsun değil mi, evini barkını terk edip kaçan adamın halini görüyorsun değil mi, görüyorsun. Boş hayal. Hep boş hayal. Boş hayallerle oluyor bunlar. Boş hayaller adamı ne yapar biliyor musun Gaza, böceğe çevirir. Bö- 
ceğe çevirir, böceğe. Girersin bir deliğe, orada birbirini yersin". Ahad'ın bakış açısından Suriyeli göçmenlerin Avrupa yolculuğu boş bir hayalin ürünü olarak görülmekte, bu anlamda göçmenler boş bir hayalin peşinden sürüklenmekte ve bu hayal uğrunda yersiz bir sıkıntıya katlanmaktadır. Ahad'a göre göçmenlerin hayalleri gerçeği yansıtmadığı gibi onları böcek örneğinde olduğu gibi sürekli ezilmeye mahkûm etmektedir. Bu anlamda, göçmen kaçakçıları açısından göçmenlerin yersiz-yurtsuz olmaları, onları yok edilme tehdidiyle baş başa bırakmakta ve onları depolara hapsetmektedir (Bkz. Resim-2).

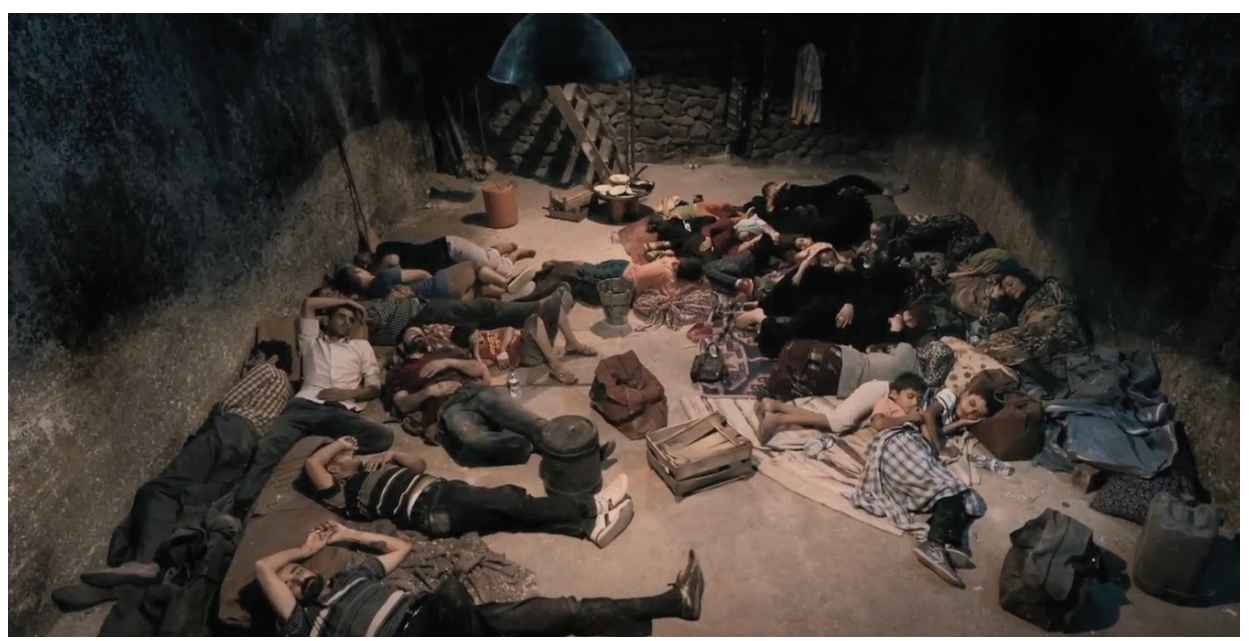

Resim-2: Kandalı'da yer alan evin deposundaki Suriyeli kaçak göçmenler

Göç kuramlarından biri olan ilişkiler ă̆ı kuramı göçün nedenleriyle değil, göçün sürekliliği ve kendini yeniden üretmesiyle ilgilenmektedir. Ağlar göç kanallarının kurumlaşmasını ve süreklilik kazanmasını bir çoğaltan etkisiyle sağlamaktadır. Aynı zamanda göçmene geniş bir hedef ve faaliyet seçimi imkânı sunmaktadır. Bazı enformel ağlar göçmenin seyahat ederek, kalacak yer ve iş bulma sürecini finanse etmektedir. Bazen firmalar işçi temin edecek aracılar kullanmakta, bazen de göçmen kaçakçıllğı yapan suç şebekeleri işin içine girmektedir. Göçmenlerin sınırı geçmelerine yardım ederek, işin zorluğuna göre hizmetlerine karş1lık on binlerce dolar talep edebilmektedir. Bu ağlardan yararlanan göçmenler çoğu zaman aldıkları ücretleri borç ödemekte kullanmak zorundadır. Bu göçmenler bask1, şiddet ve tehditlere maruz kalabilmektedir. Böylece 'göç endüstrisi' olarak adlandırılan, işe yerleştirme ajansları, avukatlar, göçmen kaçakçıları ve diğer aracı kişilerden oluşan, göçmenlere hem yardım eden hem de onları istis- 
mar eden karmaşık bir yapı ortaya çıkmaktadır. ${ }^{21}$ Filmde, kaçak göçmenler Suriye'den Avrupa'ya göç ederken, Türkiye'deki aracı yapıların yani göçmen kaçakçılarının içerdiği ağlar üzerinden hareket etmişlerdir. Belirli ücretler karşılığında sinırlardan kaçak yollarla geçirilerek bir sonraki bölgeye, kente ya da ülkeye geçirilen göçmenler, göçteki ilerleyişlerini ilişkiler ağ kuramının da vurguladığ 1 gibi göçmen kaçakçıllğı yapan suç şebekeleri vasıtasıyla gerçekleştirmişlerdir. Göçün başlangıcından bitişine dek hemen her evrede göçmen ilişkiler ağ 1 yard1miyla hareket eden göçmenler, ancak bu ağlar üzerinden hedeflerini gerçekleştirebilmektedir. Bu bağlamda, filmdeki kamyoncu Ahad, oğlu Gaza, tekneciler Harmin ile Dordor ve göçmenleri sazlıkların içinden geçirip teslim eden Osman, bir bütün olarak göçmen kaçakçılığının ilişki ağlarında yer alan kişilerdir.

\section{Göçmen Kaçakçılığının Değişmeyen Yüzü: Şiddet, Tecavüz, Fuhuş ve Ölüm}

Göçmen kadınlar çok yönlü sömürülmeleri, en zor ve kalitesiz işlerde çalıştırılmaları, hemen her gün yoğunluklu olarak şiddete, tacize ve tecavüze maruz kalmaları, hatta kadının kendisini pazarlamaya zorlanması gibi nedenlerden dolayı, birçok uluslararası kurum tarafından 21. yüzyılın köleleri olarak adlandırılmaktadırlar. ${ }^{22}$ Filmde, göçmen kadınlar şiddet, tecavüz, fuhuş ve ölümle iç içe geçmiş vaziyette görülmektedirler. Burada vurgulanması gereken önemli bir nokta, tecavüz, fuhuş ve ölümün aynı zamanda bir şiddet eylemi olduğu yönündedir. Filmde, tecavüz, fuhuş ve ölümün dışında diğer şiddet eylemleri de görüldüğg̈ için bu kavramlar birlikte kullanılmıştır. Filmde, Ahad'ın şiddet içeren davranışları, baştan sona filmin her alanına yansımıştır. Sadece göçmenlere değil, aynı zamanda oğlu Gaza'ya ve birlikte iş yaptığ davranış ve söylemlerde bulunan Ahad, kaçak göçlerin beraberinde doğurduğu şiddet eylemlerini göstermesi bakımından önemli bir örneği teşkil etmektedir. Ahad'ın şiddet içeren davranışları yakından incelendiğinde, sözel, duygusal, fiziksel, etnik, cinsel şiddet türlerinin hepsinin izlerini görmek mümkündür. Şiddetle birlikte Ahad, göçmen kadınlara tecavüz eden ve onları fuhuş amaçlı kullanan ve çocuğu ölüme terk eden davranışlara da sahip biri olarak karşımıza çıkmaktadır. Film boyunca göçmenlere bağıran, onları itip kakan, onlara küfreden, onları tecavüzle karşı karşıya getiren, onları fuhuşa sürükleyen ve çocuğu öldüren göçmen kaçakçıları insanlık onuruyla bağdaşmayan muamelelerde bulunmuşlardır. İnsan ticaretiyle karşılaştırıldığında her ne kadar "göçmen kaçakçılığında istismar ama-

21 Gülay Toksöz, a.g.e., s. 21.

22 Mustafa Peköz, Küresel Kapitalizm ve Göçmenlik, İstanbul, Karakoyun Yayınları, 2012, s. 214. 
c1 olmadığı" 23 ya da "insan ticareti kavramında istismar önemli unsurken insan kaçakçılığı kavramının en önemli unsuru para karşılığında yasa dışı sınır geçmeyi sağlamak"24 olduğu vurgulansa da, filmde, göçmen kaçakçılarının doğrudan doğruya göçmen kadınları istismar ettikleri görülmektedir. Göçmenlere yönelik şiddet, tecavüz, fuhuş ve ölüm içerikli davranışlarda bulunan Ahad, oğlu Gaza'yı da hem kendi suçlarına ortak etmeye çalışmakta hem de onu kendisi gibi yetiştirmenin gayreti içerisindedir. Bu konuda oğlu Gaza'nın eğitimine bütünüyle karş1 çıkan Ahad, oğluna sürekli olarak kendisini örnek almasını vurgulamaktadır. Bununla ilgili olarak Ahad, oğlu Gaza'ya şunları ifade etmektedir: "sen de bırak çalışmayı malışmayl, (ne yapcam peki?), neyi ne yapcan lan, ben ne yapıyorsam onu yapacaksın. Buradan mis gibi okula gidip geleceksin işte, Kandalı'nın suyu mu çıtıtı? Senin bundan sonra bir tane sınavın var, o da benimle. Artık çıraklık bitti, ortağız biz. Bir sen bir de ben. Bizim bizden başka kimsemiz yok. Anladin mi? Öğreteceğim sana, hepsini öğreteceğim, hiç merak etme. ... bu hayatta iki şeye güveneceksin, bir paraya, iki bana." Ahad için aslolan eğitim değil, paradır. Eğitim gereksiz bir şey görünürken, para en yüce, en kutsal varlık olarak tanımlanmaktadır. Gaza'dan beklenilen, babası Ahad'ın yolundan gitmek, babasına ve paraya değer verip, kendi eğitiminden ve ideallerinden ödün vermektir. Oğlu Gaza'yı bu şekilde yetiştirmeye çalışan Ahad, ekonomik açgözlülüğü sebebiyle oğlu Gaza'nın âşık olduğu Suriyeli göçmen kadın Ahra'yı da fuhuş amaçlı kullanmış ve Gaza'nın durumu fark etmesi sonrasında Ahad, oğlu Gaza'ya sözel ve duygusal şiddetle birlikte fiziksel şiddet uygulamıştır. Ahad'ın oğlu Gaza'ya şiddet uygulamasının arkasında yatan ana sebep, Gaza'nın kendi işine çomak sokması, bu anlamda devam edegelen düzenini alt üst edecek davranışlarda bulunmasıdır.

Öte yandan filmde Ahad, oğlu Gaza'yı kendisi gibi yetiştirmeye çalışırken göçmenlere uyguladığı şiddet, tecavüz, fuhuş ve ölüm gibi olaylar karşısında kendini meşrulaştırmanın gayreti içerisinde olmuştur. Diğer bir ifadeyle, Ahad, göçmenlerin maruz kaldığı şiddet, tecavüz, fuhuş ve ölüm gibi olayların, onların içinde bulundukları durumlar göz önüne alındığında, kaçınılmaz olduğunu oğlu Gaza'ya anlatarak kendi yaptıklarına meşru bir zemin oluşturduğu gözlenmiştir. Nitekim şiddet, tecavüz ve fuhuştan hemen sonra oğlu Gaza'yla tartışan Ahad, kendi yaptıklarını meşru göstermek için oğluna şunları söylemektedir: "Hiçbir şey görmedin, hiçbir şey olmad, unut. Ulan biz bu işleri nasıl bu kadar kolayca rahat yapıyoruz. Hiç düşündün mü, hiç biliyor musun? Para isterse para, karl isterse karl veriyorum. İ̧ yapıyorum lan ben onunla, iş yapıyorum. O pezevenk,

23 Yusuf Adigüzel, a.g.e., s. 118.

24 Ahmet İçduygu, a.g.e., s. 24. 
ne isterse veriyorum. Sen o kuz buraya kadar nasll geldi biliyor musun, yok. Nereden geldi biliyor musun, yok. Nereye gidiyor biliyor musun, yok. Demek ki hiçbir bok bilmiyorsun. Sen bugüne kadar ne yaptın lan hayatta kalmak için, neyini feda ettin, neden vazgeçtin? Kurt gibi geçireceksin hayata dişlerini, kurt gibi. O kız onu yapıyor işte". Ahad, göçmen kadınların uğradıkları şiddetin, tecavüzün ve fuhuşun gerekçesi olarak onların hayatta kalmak için yaptıklarını, kendilerini feda ettiklerini ve pek çok şeyden vazgeçtiklerini vurgulamakta ve bu sayede olup bitenden kendisinin sorumlu olmadığını, kendisinin sadece para kazanmak amacıyla bu işlerin içerisinde olduğunu anlatmaktadır. Kendisinin salt para kazanmak için bu işi yaptığını, bu işlerin de tahmin edildiğinden zor olduğunu, yani kazandığı parayı ne zorluklar içerisinde kazandığını vurgulayarak, kendisini ve göçmen kadınları masum göstermeye çalıştığı anlaşılmaktadır.

Filmde şiddet, tecavüz, fuhuş ve ölümlerin odağında ağırlıklı olarak kadınlar, çocuklar ve hastalar bulunmaktadır. Göçmenler içerisinde en savunmasız durumda olan ve bu sebeple her türlü insanlık dışı muamelelere maruz bırakılan kadınlar, çocuklar ve hastalar, göçmen kaçakçılarının insafına terk edilmiş vaziyettedirler. Filmde kadınlar şiddete, tecavüze ve fuhuşa sürüklenirken, çocuklar ve hastalar ölümle sonuçlanan olayların bir parçası olmuşlardır. Filmde Ahad, göçmen bir kadına tecavüz ederek, bu tecavüz üzerinden göçmen kadınların bedenine hükmeder hale gelmiştir. Elif Özer'in de vurguladığı gibi, insan ticaretinde kadın bedeni ağır bir şekilde risklere açık hale gelir. Çok sayıda korunmasız cinsel ilişkiye zorlanmanın psikolojik tahribine, istenmeyen gebelikler, cinsel yollar bulaşan enfeksiyonlar, tedaviye erişememe gibi hak ihlalleri ve cinsel sağlik tehlikeleri de eklenebilir. Mağdurların uğradığ cinsel şiddet, bedenlerinin kontrol edilmesi ve sağlık riskleri eksenlerinde açılabilir. ${ }^{25}$ Filmde göçmen kadına tecavüz edilirken tecavüze uğrayan kadının çocuğu da ölüme terk edilmiş ve daha sonra bir kuyuya atılarak üzeri toprakla örtülmüştür. Yine hastalanan erkek bir göçmenin, diğer arkadaşının çabalarına rağmen tedaviden mahrum bırakılarak ölmesine göz yumulmuştur. Bu tablo, göçmenlerin her türlü şiddete uğradıklarını, tecavüz edildiklerini ve ölüme terk edildiklerini göstermiştir. Bununla birlikte, filmde, Gaza'nın âşık olduğu kadının Gaza'nın babası Ahad tarafından fuhuşa sürüklendiği görülmektedir. Para karşılığında başka kişilere pazarlanan göçmen kadınlar, göçmen kaçakçılarının maksimum kar elde etme amaçlarının kurbanı haline gelmektedirler. Emel Coşkun'un da vurguladığı gibi, “göçmen kadınlar Türkiye'nin göç ve fuhuş rejimleri içerisinde oldukça kırılgan ve cinsiyetçi şiddete açık bir

25 Elif Özer, Kimse Duymaz: Türkiye'de İnsan Ticareti Mağdurları Üzerine Bir Araştırma, Ankara, Ayizi Yayınları, 2012, s. 122. 
konumda bulunuyorlar. Fuhuş yasası ve denetim mekanizmaları sadece kadınları kriminalize etmekle kalmıyor, özellikle de göçmen kadınları gönüllü fahişe olarak resmederek onları sözde-rızaları üzerinden her türlü şiddete ve sömürüye karşı daha da savunmasız hale getiriyor. Bu koşullara rağmen, göçmen kadınlar genellikle izinsiz fuhuş yapma nedeniyle gözaltına alınırken bazen de seks ticareti mağduru olarak tanımlanabiliyor." 26 Filmde de görüleceği üzere, göçmen kadın, rızası olmadan, kaçakçının para karşılığında cinsel ilişkiye zorlanmasıyla fuhuşa dâhil olmaktadır. Bu anlamda göçmen kadınlar, kaçak göç süreçlerinde her türlü şiddetin, bu anlamda tecavüzün, fuhuşun ve ölümün potansiyel adaylarına dönüşmektedir.

İnsan ticaretiyle karşılaştırıldığında her ne kadar "göçmen kaçakçılığı devlet aleyhine işlenen bir suç"27 olarak tanımlansa da, esasında insan ticaretini içeren ve bu anlamda sadece devlete karşı değil, aynı zamanda kişiye karşı da işlenen ve insan haklarını ihlal eden boyutlar taşımaktadır. Her ne kadar "kaçakçı ile yasadışı göçmen arasında mesafeli ancak saygılı bir ilişki yaşanmaktadır. Kaçakçı, müşterisi niteliğindeki insanlara şiddet uygulamamakta, göçmenle ters düşmek ve kalabalık bir topluluğu karşısına almak istememektedir" ${ }^{28}$ şeklinde vurgular bulunsa da, filmde, göçmen kaçakçılarının kaçak göçmenlere mesafeli ve saygılı davranmadığı, onlara şiddet uyguladığı, onları tecavüzün, fuhuşun ve ölümün pençesine terk ettikleri, onlarla ters düştüğü ve bu anlamda onları karşısına aldıkları görülmüştür. Bu bağlamda, İçduygu'nun da belirttiği gibi, göçmen kaçakçılığı sürecinin farklı aşamalarında farklı kişilerin de dâhil olduğu firsat odaklı hareket eden küçük kaçakçılık gruplarından söz edilebilir. Ancak bu durum insan kaçakçılığının içinde hiçbir insan ticareti özelliği barındırmadığı anlamına gelmez; bazen insan kaçakçılığı insan ticaretiyle eklemlenir. ${ }^{29}$ Filmde de görüldüğü üzere, insan kaçakçılığı ile insan ticareti arasındaki çizgiler giderek ortadan kalkmış, göçmen kaçakçıları aynı zamanda göçmenlerin ticaretini de yapan kişiler olarak ön plana çıkmışlardır.

\section{Hadi Bin Vur Bir Say: İktidar Mücadelesi, Direniş ve Yeniden Tahakküm}

Film, baba Ahad ile oğul Gaza'nın iktidar mücadelesini içermektedir. Bir tarafta oğlu Gaza'yı kendisi gibi yetiştirmeye çalışan, kendi suçlarına onu ortak eden, kendi otoritesini mutlaklaştırmak amacıyla ona şiddet uygulayan ve

26 Emel Coşkun, “Türkiye'de Göçmen Kadınlar ve Seks Ticareti”, Çalışma ve Toplum, 42, 2014, s. 197.

27 Yusuf Adigüzel, a.g.e., s. 118.

28 Bülent Çiçekli, Oğuzhan Ömer Demir, a.g.e., s. 128.

29 Ahmet İçduygu, a.g.e., s. 41. 
onun eğitimini ve ideallerini hiç önemsemeyen bir baba kimliğine sahip Ahad bulunurken, diğer tarafta babasının yaptıklarını başlangıçta kabul eden, onun otoritesini sorgulamayan, göçmen kaçakçıllğında ona destek veren ve onun gibi davranışlarda bulunan ama daha sonra babasının otoritesini yok sayan, ona karşı gelen, kendi eğitiminin peşinden gitmek isteyen, kendi idealleri için Kandalı'dan kaçıp kurtulmaya çalışan ve sevdiği göçmen kadının babası tarafından fuhuş amaçlı kullanılmasından sonra babasının ölmesine sebep olan, bu anlamda bütünüyle babasını hiçe sayan bir oğul kimliğine sahip Gaza yer almaktadır. Film bir anlamda göçmen kaçakçılığı içerisindeki iktidar mücadelesini ele almakta ve bu mücadelenin serimlediği alanları bütün boyutlarıyla sunmaktadır.

Başlangıçta babasına omuz veren ama daha sonra onun otoritesine karşı ç1kan Gaza'nın direnişi çift yönlüdür. Gaza, bir taraftan babası Ahad'a karşı direnişini bir "direniş ateşi” yakarak göstermiştir (Bkz. Resim-3). Üstelik direniş ateşini tutuşturmak için kullandığı kâğıtta dünya resminin olması, Gaza'nın direnişinin dünyayı yakabilecek boyutta olduğunu vurgulamaya dönük mesajlar içermektedir. Diğer taraftan Gaza, babasına karş1 olan direnişini, bir "direniş müziği” söyleyerek ortaya koymuştur (Bkz. Resim-3). Gaza'nın direniş müziği, aynı zamanda filmin müziğini de oluşturan "hadi bin vur bir say" söyleminde karşılığını bulmaktadır. Filmde kentli grupların müziği olan "hadi bin vur bir say”, Gaza'nın İstanbul gibi büyük kente göç etme ideallerinin bir parçasına dönüşmüştür. Babası Ahad'ın otoritesine karşı bir direniş içerisinde yer alan Gaza, direnişi "hadi bin vur bir say" diyerek ifade etmiştir. "Hadi bin vur bir say" müziği, filmde başlangıçta kentli grupların müziği iken, daha sonra Gaza'nın direnişinin sembolü haline dönüşmüştür. Filmde Gaza, babasının kötülüklerine ve kendisine uyguladığı her türlü şiddete karşı olarak müziğin sözlerini babasına şu şekilde söylemiştir: "Hadi bin vur bir say. Hadi bak bu Gaza, bin vur bir say. Hiç acımadı lan, bin vur bir say. Hadi kafama kafama bin vur bir say. Hadi tam buraya bin vur bir say. Hacı cavcav kafama kafama. Hadi baba kafama kafama bin vur bir say. Hadi baba bana bin vur bir say". Gaza, şark1 sözlerine baba kelimesini de dâhil ederek, "hadi baba bin vur bir say" şeklinde sözleriyle babasının otoritesine karşı bir direniş ortaya koymuş ve Gaza'nın bu direnişi, Ahad'ın iktidarını önemli ölçüde sarsıntıya uğratmıştır. Bu bağlamda, baba ile oğul arasındaki çatışma, esasında göçmen kaçakçılığının kendi içinde nasıl bir iktidar mücadelesini içerdiğini ve kendi aralarındaki ilişki biçimlerini göstermektedir. Baba-oğul arasındaki çatışma, aynı zamanda düzensiz göç süreçlerini de önemli ölçüde betimlemektedir. 


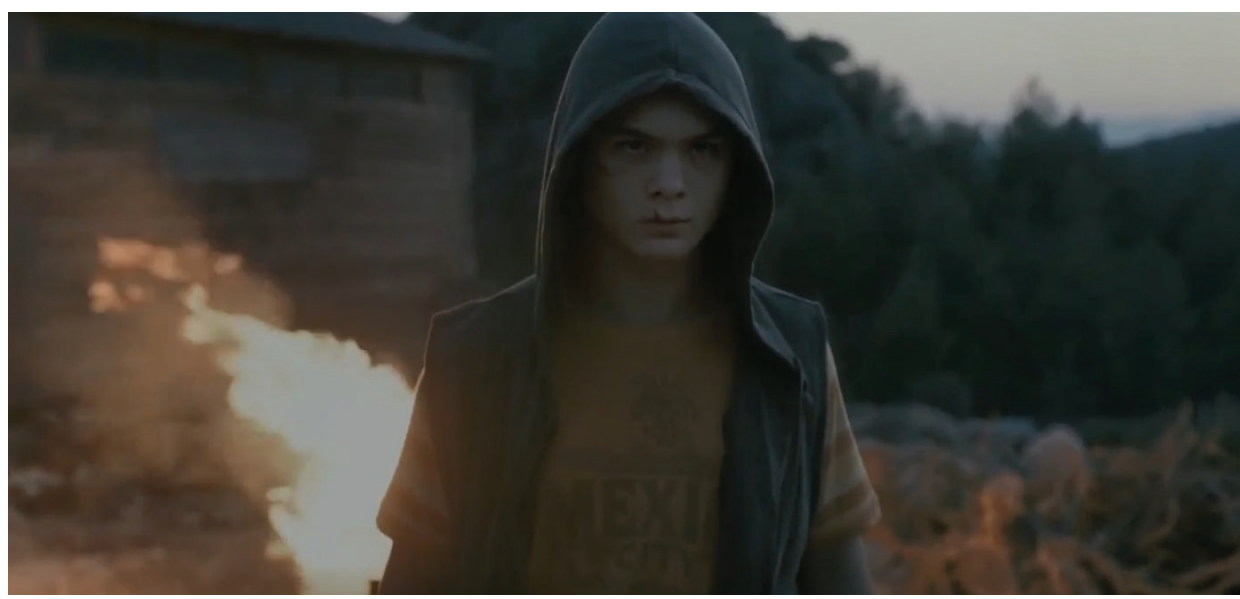

Resim-3: Gaza'nın direniş ateşini yakması ve direniş müziğini söylemesi

Gruplar mekânda ancak göreli bir kalıcılığa sahip oldukları ve üyelerinden bazıları da uzlaşabildiği için, bir bireyi ilgilendiren bir olay grubu ancak belli bir süre, yani bireyler birbirlerine yaklaştıkça ve birinin eylemi ya da durumu diğerlerinin var olma biçimlerini ve yöntemlerini etkilediği ya da etkileyebildiği ölçüde de ilgilendirir. Grubun dönüşümü ise, şu ya da bu üyenin ayrılmasının sonucu değildir sadece; bireylerin rolleri ve durumları da aynı toplumun içinde durmadan değişir. ${ }^{30}$ Ahad'ın iktidarını direnişle sarsıntıya uğratan Gaza, babasını diğer göçmen kaçakçısı teknecilere şikâyet ederek onun öldürülmesine neden olmuş ve bu sayede bütünüyle babasından kurtulmuştur.

Ahad'a karşı direnişinde hem bir başarı hem de bir intikam elde etmiş olan Gaza, Ahad sonrası düzende, kaçak göçmenlere çare olmak yerine onlar üzerinden yeniden tahakküm kurmuştur. Kandalı'yı terk edip İstanbul'a yerleşmek, eğitimine devam etmek gibi hayallerinin, ideallerinin peşinden gitmek yerine Kandalı'da kalıp babasının işini yapmayı sürdürmüş, bu anlamda kaçak göçmenlerin saklandığı depoyu yönetmeye devam etmiştir. Gaza, hem kendi içinde bulunduğu durumu hem de kaçak göçmenleri yönetmeyi şu şekilde ifade etmiştir: "Hiçbir mahkûm benim kadar hayal etmemiştir kaçmayı. Hiçbir mahkûm benim kadar denememiştir. Ama insanın kendi gardiyanı olduğu bir hapishaneden kaçması o kadar zor ki. Benim hapishanem o insanlarda, bir lağımdı aslında o depo, içinden insan geçen bir lağım. Tıkanmasın diye uğraşıyordum. Ve madem bir lağımdan sorumluydum, ben de o lağımın Tanrısı olurum dedim. Tanrı olmak

30 Maurica Halbwachs, Hafızanın Toplumsal Çerçeveleri, çev. Büşra Uçar, Ankara, Heretik Yayınlar1, 2016, s. 171-172. 
o kadar zor değil. Insanlar her şeye inanmaya hazırdl. O kadar korkuyorlardl ki. Bana bile inandılar". Gaza'nın içinde bulunduğu durum aslında çelişkilerle doludur. Bir taraftan kaçıp kurtulmak isterken, kendisinin hem mahkûm hem de gardiyan olduğunu, diğer taraftan da gitme imkânı doğmuşken, kaçak göçmenlerin yer aldığı deponun yönetiminin kendisine kaldığını, depoda yer alan kaçak göçmenlerin kendisine koşulsuz inanmaları sebebiyle, kendisinin oranın Tanrısı olduğunu belirtmektedir. Depoyu bir lağıma benzeten, kendisini o lağımın Tanrısı olarak gören Gaza, kaçak göçmenlerin yeni yönetimin kendinde olduğunu vurgulamıştır. Ancak Gaza'nın yönetim biçimi babası Ahad'tan oldukça farklıdır. Gaza, depodaki kaçak göçmenleri farklı bölümlere ayırarak, diğer bir ifadeyle, depo içinde depolar yaparak onları birbirlerinden ayırmıştır. Dahası, depoya yerleştirdiği kamera sistemiyle kaçak göçmenleri 7/24 saat gözetim altına almış ve bu kameralarla onları leblebi yiyerek izlemiştir (Bkz. Resim-4).

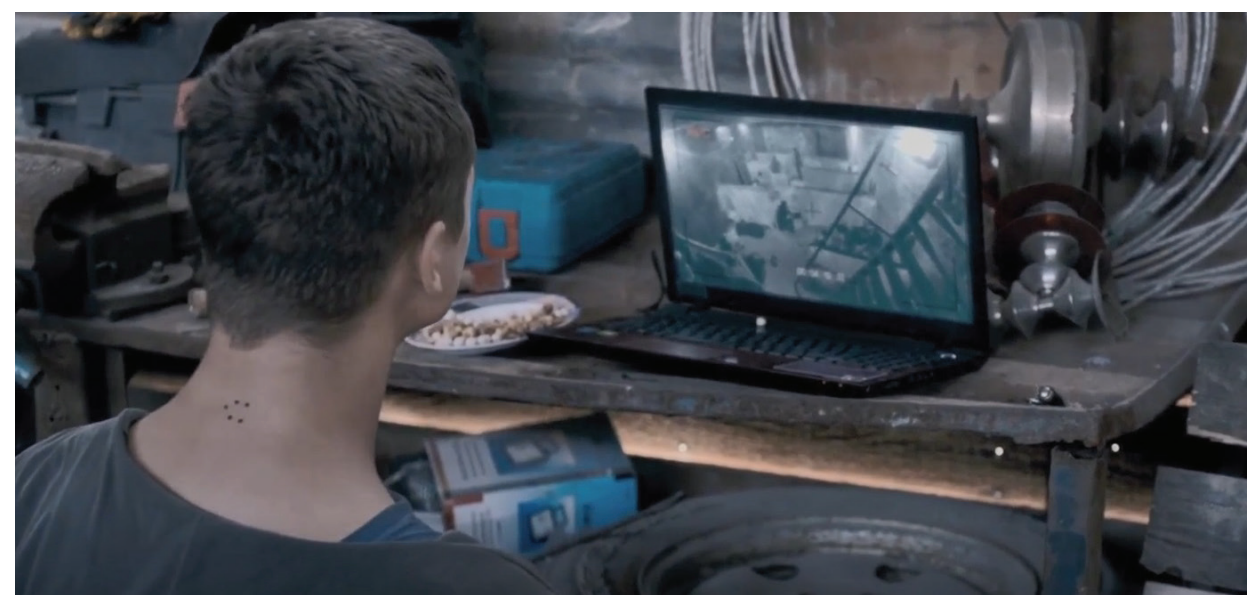

Resim-4: Gaza’nın kaçak göçmenleri kamerayla izlemesi

Kaçak göçmenleri bu şekilde izlemesi esasında Gaza'nın da babası Ahad gibi kaçak göçmenlerin acılarına duyarsızlaştığını göstermektedir. Gaza'nın depoyu sistematik bir şekilde yönetimi, babası Ahad'ın kaçak göçmenler üzerinde açtığ1 derin yara izlerine yenilerini eklemiştir. Örneğin, depoda hastalanan bir göçmenin tedavisi için diğer göçmenlerin çırpınışları karşısında Gaza sessizliğini korumuş, göçmenler için herhangi bir şey yapmamış ve göçmenleri kameradan izlemeye devam etmiştir. Filmin başında, "benim adım Gaza, ben dünyanın en önemli adamının oğluyum" derken, gelinen noktada kendisini dünyanın en önemli adamı olarak konumlandırmıştır. Babası Ahad'ın yapıp ettiği bütün kötülükler karşısında, "hadi baba bin vur bir say” diyerek direniş gösteren Gaza, babasının 
ölümünden sonra göçmenler üzerinde yeniden tahakküm kurmuş ve bu kez kendisi göçmenlere bin vurup bir sayar hale gelmiştir.

\section{Semboller, Toplumsal Hafıza Mekânları ve Göçmen Kimliği}

Sembol dediğimiz şey nedir? Sembolün tanımı, çoğunlukla, başka bir şeyin yerinde duran, onun yerini alan, onu temsil eden olarak yapılmaktadır. Bu haliyle bu tanımı pek anlayamayız. Fakat beş duyumuzu da bazı sembollerle temsil edebileceğimizi düşünür ve bu sembolleri inceleyecek olursak, konu biraz daha ilginçleşecektir. Bunu yapmak için, sözü edilen bu sembollerin bir tecrübenin, bir duygunun ya da bir düşüncenin yerine geçtiğini varsaymamız gerekecektir. Böyle bir sembol, benliğimizin dışını yansıtmaktadır. Sembolize ettiği şey ise içimizde saklıdır. ${ }^{31}$ Sembol dediğimiz, gündelik yaşamımızdan bilip tanıdığımız ama alışılagelen, açık anlamına ek olarak özgün bağlantılar sunan bir terim, bir ad hatta bir resimdir. Bunda belirgin olmayan, bilinmeyen ya da bizim için görünür olmayan bir şeyler vardır. ${ }^{32}$

Semboller, içerdiği anlamların toplumsal taşıyıcıları olarak farklı zaman ve mekânda değişik anlamları ihtiva etmektedirler. Sembollerin içerdiği anlamlar, toplumsal hafızalar vasıtasıyla geçmişten günümüze varlığını sürdürmekte ve sembollerin toplumsal yaşam üzerindeki etkileri, toplumsal hafıza mekânları üzerinden görünür hale gelmektedir. M. Emir İlhan'a göre, hatırlama, bir kişinin zihninde tek başına yapabileceği bir şey olsa da, hatırlanan içerik bakımından tek başına olabilecek bir eylem değildir; demek ki toplumsal eylemdir. Hatırlanan bu içerik insanın toplumsal varoluşunun, diğer insanlarla olan ilişkileri ve etkileşimleri tarafından oluşturulur. Bu bakımdan hatırlama toplumsal eylemdir. ${ }^{33}$ Özlem Özdemir'e göre ise, neyin hatırlanıp, neyin hatırlama çerçevesinin dışında tutulduğunun; nasıl hatırlandığ1 ve unutulduğunun anlaşılması, toplumsal değişimi ve bu değişime yönelik baskıların yönünü anlamlandırma konusunda yeni imkânlar sunmaktadır. ${ }^{34}$ Filmde göçmen kaçakçılarının ve kaçak göçmenlerin toplumsal durumlarını anlamada sembollerin ve toplumsal hafıza mekânlarının belirgin iş-

31 Eric Fromm, Rüyalar, Masallar, Mitoslar, çev. Aydın Arıtan, Kaan H. Ökten, İstanbul, Arıtan Yayınevi Yayınları, 1992, s. 24-25.

32 Carl Gustav Jung, İnsan ve Sembolleri, çev. Ali Nahit Babaoğlu, İstanbul, Okyanus Yayınları, 2009, s. 20.

33 M. Emir İlhan, Kültürel Bellek: Sözlü Kültürden Yazılı Kültüre Hatırlama, Ankara, Doğu Batı Yayınları, 2018, s. 25.

34 Özlem Özdemir, "Geçmişe Mazi Diyebildik mi? Bir Bellek Mekânı Olarak Sinema”, Neye Yarar Hatıralar? Bellek ve Siyaset Çalışmaları, der. Pınar Melis Yelsalı Parmaksız, Ankara, Phoenix Yayınlar1, 2012, s. 163. 
levleri bulunmaktadır. Çünkü toplumsal hafıza mekânlarındaki semboller, esasında içerdiği anlamlar aracılığıyla göçmen kimliğinin inşasına önemli katkılar sunmaktadır. Göçmen kimliğinin anlaşılması sürecinde eldeki kısıtlı imkân ve potansiyeller olduğu durumlarda semboller her zamankinden daha fazla işlevsel hale gelmektedirler. Filmde yer alan semboller, çok farklı algıları ve anlamlandırma pratiklerini gün yüzüne çıkarmakta ve göçmenlerin kimlikleri hakkında bizlere önemli ipuçları ortaya koymaktadır.

Ömer Aytaç’ın da vurguladığı gibi, toplumsala dair zihinsel arketipler, bilişsel haritalar mekâna sinmiştir ve mekânsal olan, yaşamın, tarihin, bellek ve kimliğin konfigürasyonlarıyla bizi yüzleştirir, bir bakıma, zamanın ruhuna bizi tanık kılar. Mekân bir bakıma, zamanın, düşünce ve imgelem dünyalarının yansıdığı birer ayna gibidir. Her zamanın ve her toplumun farklı mekân temsilleri vardır. Mekân, toplumsallığın, politik olanın, kültürel ve düşünsel imgelerin sindiği, vücut bulduğu bir gerçekliğe karşılık gelir. Bu yönüyle nötr bir form değil, aksine, politiktir ve toplumsallığın türlü ifade araçları için işlevsel bir araç durumundadır. Mekân, bu açıdan, sosyolojik bir formdur. ${ }^{35}$ Alver'e göre, bir hafıza birimi olan mekân, insana dair pek çok şeyi taşır, temsil eder, tanımlar ve gösterir. İnsanın unuttuğu, hayatın hızına kurban verdiği kimi ayrıntıları mekâna depolar. Mekân söz, dil, hatıra, mana haline gelir; büyük hafızaya kapı olur. Çünkü mekân kendine dokunan, bakan ve kendini dokuyan o hayatı, o hatırayı muhafaza eder, hafizasına alır ve zaman zaman bu hazineden hisseler dağıtır. Kolektif hafizanın kaydedilmesi, sürdürülmesi ve taşınması için mekânın varlığı önem arz eder. Hafıza mekâna ihtiyaç duyar; mekânsal inşayı gerektirir. Mekân, hayatı tutar, saklar, barındırır, zamanın unutturan rüzgârına karşı korur. ${ }^{36}$

Filmdeki kaçak göçmenler açısından Kandalı, bugün gelinen ancak yarın gidilecek olan mekanı işaret etmektedir. Bu mekândaki ilişkiler, evin deposu olarak bilinen bir kapanın içerisinde gerçekleştirilmektedir. Depo, kaçak göçmenlerin hafızasında şiddetin, tecavüzün, fuhuşun ve ölümün izlerini taşımaktadır. Göçmenler bu depo içerisinde bekletildikleri süre içerisinde deponun duvarlarına çeşitli semboller çizmişlerdir (Bkz. Resim-5). Bu semboller, göçmen kimliğini anlamada birbirinden farklı sonuçlar ortaya çıkarmıştır. Bu semboller vasıtasıyla göçmenler içinde yer aldıkları mekâna hayallerini, özlemlerini, umutlarını, isteklerini, yardım çığlıklarını, arzularını, dileklerini resmetmişlerdir. Bu sembollerin

35 Ömer Aytaç, “Mekân(1n) Sosyolojisi: Toplumsalın Yeniden Kuruluşu”, Sosyoloji ve Coğrafya (Sosyoloji Yıllığı - Kitap 15), yay. haz. Ertan Eğribel, Ufuk Özcan, İstanbul, Kızılelma Yayınc1lik, 2006, s. 881.

Köksal Alver, "Mekân ve Hafiza", Sosyoloji Divanı, 10, 2017, s. 271. 
içerdiği anlamlar, hem göçmenlerin kimliğine ilişkin önemli veriler ortaya koymuş, hem de depoyu bir toplumsal hafiza mekânına dönüştürmüştür.

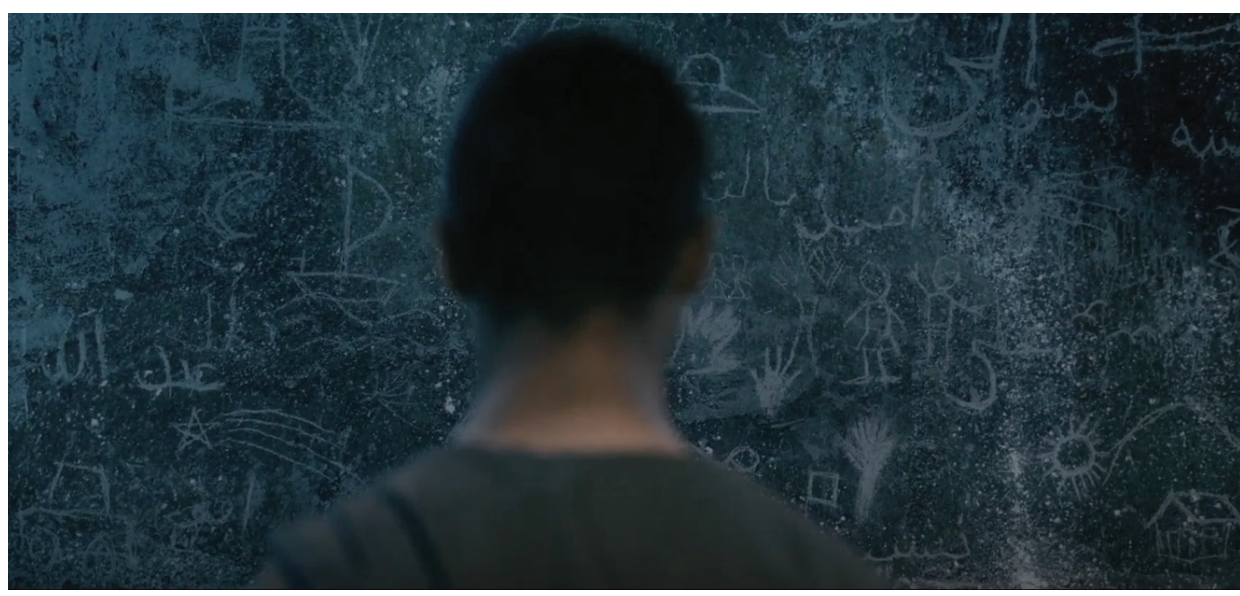

Resim-5: Göçmenlerin kaldıkları deponun duvarına kazıdıkları semboller

Kuş, özgürlüğü sembolize etmektedir. Göçmenlerin kaçak yollarla ve kaçakçıların tekelinde depo tarzı koşullar içerisindeki yaşamlarından kurtularak özgürlüklerine kavuşmak isteği görülmektedir. Göçmenlerin günün birinde özgürlüklerine kavuşmak umudu, kuş üzerinden sembolize edilmiştir.

Uçak, yere olan bağımlılıktan kurtuluşu ve gökyüzünde olmakla tıpkı kuş gibi özgürce uçabilmeyi isteyen ancak göçmen kaçakçılarına bağımlı olan göçmenlerin durumunu sembolize etmiştir.

$E l$, göçmenlerin karşılaştıkları zorluklar, uğradıkları zulümler ve yaşadıkları kötülükler karşısında yardıma muhtaç pozisyonda olduklarını ifade etmek amacıyla el sembolünü duvara kazımışlardır. Şiddetin her türlüsünü yaşayan, tecavüze uğrayan, fuhuşa sürüklenen ve ölüme terk edilen göçmenler, insanlıkla bağdaşmayan bu muameleler karşısında yardım elini beklediklerini ifade etmektedirler.

Sandal, göçmenlerin kaçak yollardan geçtiklerini sembolize etmektedir. Suriye'den Avrupa'ya gitmek isteyen göçmenlerin sandallar üzerinde göç etmeyi göze aldıkları görülmektedir. $\mathrm{Bu}$ anlamda sandal, göçün içerdiği risklere işaret etmektedir.

Otomobil, göçmenlerin göç biçimlerinin diğer bir yüzünü, yani taşınma biçimlerini sembolize etmektedir. Göçmen kaçakçıları tarafından kamyonetlerin kasasına tıka basa doldurulan göçmenler için otomobil, kamyonetlerin kasaların- 
da taşınmak yerine, özgürce seyahat edebilmeyi sembolize etmektedir. Diğer bir ifadeyle, göçmenler, hayalini kurdukları göç örüntülerini sembolize etmek için otomobili sembol haline getirmişlerdir.

Güneş, göçmenlerin aydınlık günlere olan beklentilerinin, umutlarının ve arzularının bir yansıması olarak belirmiştir. Göçmenlerin nasıl bir karanlığa sürüklenmiş olduklarını anlatan güneş, bu anlamda göçmenlerin bir gün üzerine doğacak olanı sembolize etmiştir.

$A y$, göçmenler için karanlığın içinden doğan bir 1şık, bir yol gösterici, bir aydınlık anlamlarını sembolize etmektedir. Ay'ın karanlıkta belirmesi, göçmenlerin umuduna işaret etmektedir. Bu anlamda göçmenler, içinde bulundukları karanlıktan bir çıkış anlamında ayı sembolize etmişlerdir.

Çocuklar, göçmenler içerisindeki en dezavantajlı durumda olanların başında gelmektedir. Çocukların göç süreçlerinde yıpranması, her türlü kötülüklerle karş1laşması ve daha da önemlisi ölüme terk edilmeleri sebebiyle, çocuk resimleri, çocukların çocuk gibi yaşadıkları bir dünyayı imgelediklerini sembolize etmiştir.

$E v$, kaçak göçmenlerin evsiz ve vatansız olduklarını/kaldıklarını, bu bakımdan kaçakçıların evlerinin depolarında yaşamak yerine, kendi evlerinde yaşamak istediklerinin bir ifadesi olmuştur. Evsiz kalmak, göçmenler için güvensizlik anlamını taşıdı̆̆ından, kendi evinde yaşama arzusu göçmenler açısından daha güvenli bir yaşam demektir ve ev sembolü, göçmenlerin daha güvenli bir dünya arzularının bir ürünüdür.

A ̆gaç, göçmenlerin umudunu yeşerten ve onu güçlü kılan özellikler içermektedir. Ancak duvardaki ağaç resmi, yaprakları dökülmüş olup, göçmenler için depodaki yaşam, umudun tükenmiş olduğunu sembolize etmektedir. Ancak ağaç her ne kadar yaprakları dökülmüş olsa da, yeniden yeşereceği için, göçmenler için de umudun yeniden oluşacağını göstermektedir. Diğer bir ifadeyle, yapraklarını dökmüş ağaç, göçmenlerin taşıdığ 1 umudun her ne kadar sönmüş olursa olsun, her zaman yeniden yeşereceğini sembolize etmektedir.

Kayan Yıldız, göçmenler için dilek, istek, umut gibi anlamları çağrıştırmaktadır. Bu anlamlar içerisinde özellikle de dilek anlamı daha fazla ön plana çıkmaktadır. Çünkü göçmenlerin gökyüzüne baktıklarında, yıldızın kaymasına koşut olarak sürekli dilek tuttuklarını göstermektedir. Bu anlamda kayan yıldız demek, dileklerin gerçekleşmesi beklentisi demektir, göçmenler için de anlamı budur.

Allah, göçmenlerin dinsel kimliğinin Müslüman olduğunu gösterdiği gibi, kurtuluşun Allah'la geleceğine olan inancin da bir ifadesidir. Göçmenlerin neyi var sorusunun yanıtı, kuşkusuz Allah'1 var şeklindedir. Allah'1n sembolize edil- 
mesi, göçmenlerin mazlum olduğunu, zalimler karşısında Allah'ın her daim mazlumların yanında olduğunu vurgulamaya yöneliktir. Bu anlamda, duvardaki Allah yazısı, Allah'ın göçmenlere yardım edeceğinin sembolize edilmiş halidir.

Göçmenlerin deponun duvarlarına çizmiş oldukları resimler arasında yer alan kuş, uçak, el, sandal, otomobil, güneş, ay, çocuklar, ev, ă̆aç, kayan yıldız, Allah, göçmenlerin toplumsal kimliklerinin köşe taşlarını oluşturan sembollerdir. Bu sembollerin içerdikleri anlamlar, göçmen kimliğinin içeriğini oluşturan anlam haritalarıdır. Sembollerin ortaya çıkardığı anlamlar, göçmenlerin toplumsal haf1zalarını şekillendirdiği gibi, depo gibi yerleri de birer toplumsal hafıza mekânına dönüştürmüştür. $\mathrm{Bu}$ mekâna işlenen semboller, gelip geçen her göçmenin kimliğine dair ipuçları sunmaktadır. Bu anlamda söz konusu mekân, toplumsal hafizadaki farklı anlamların toplumsal taşıyıcıları olarak işlevselleştirilmiştir.

\section{Sonuç}

Bu çalışmada, Türkiye'deki Suriyelilerin kaçak göç deneyimleri, sınırların göçler üzerindeki etkileri, göçmen kaçakçılarının kaçak göçmenlere bakış açısı, göçmen kaçakçıllğının iktidar, direniş ve tahakküm biçimleri, göçmen kimliğinin sembollerle ve toplumsal hafiza mekânlarıyla olan ilişkisi, Daha filmi bağlamında sosyolojik açıdan incelenmiştir. Yapılan incelemenin ardından elde edilen sonuçları birkaç tema etrafında toparlayabiliriz.

Filmde, göçmen kaçakçıları, Suriyeli göçmenleri sınırdan kaçak yollarda geçirerek Avrupa'ya götürmeyi amaçlamış, bu amaç doğrultusunda bu göçü ekonomik kazançları için bir geçim kaynağı haline dönüştürmüşlerdir. Kaçak göçmenler üzerinden para kazanan göçmen kaçakçıları, aynı zamanda göçmen kadınlara şiddet uygulayan, onlara tecavüz eden, onları fuhuşa sürükleyen ve çocukları ve hastaları ölüme terk eden kişiler olarak karşımıza çıkmaktadır. Ekonomik açgözlülükle birlikte cinsiyetçiliğin birlikteliği, göçmen kaçakçılarının insanın onurunu ayaklar altına alan davranışlarda bulunmalarına sebebiyet vermiştir. Kaçak göçmenler ise sınırların gölgesinde göç etmeye çalışan, her defasında bir başka göçmen kaçakçısında tabi bir şekilde umuda yolculuk yapan, evlerin depolarında hayatta kalmaya çalışan, şiddetin her yüzüyle karşılaşıp, tecavüz, fuhuş ve ölümle iç içe bir yaşam sürdüren kişilerdir. Evsiz ve vatansız bir durumda olan göçmenler, sazlıkların içinden geçirilen, kamyonetlerin kasalarına tıka basa doldurulan ve teknelere sığdırılmaya çalışılan ama hedeflerinden asla vazgeçmeyen bir pozisyonun içindedirler.

Filmde, göçmen kaçakçıları, kaçak yollardan sınırı geçirmeye çalıştıkları göçmenleri, sınırların gölgesinde inşa ettikleri bir kurgusal mekânda bekletmek- 
tedirler. Kandalı olarak bilinen bu mekân, 82 plakasıyla Türkiye'nin yeni kentini sembolize etmektedir. Göçmenlerin yaşadığı bir kent olarak kurgulanan Kandalı, göçmen kaçakçılarının göçmenleri evlerinin depolarına hapsettikleri, bu anlamda kaçak göçmenlerin hiç eksik olmadığı bir mekân konumundadır. Gideni ve geleninin hiç eksik olmadığı bu kurgusal kentte, göçmen kaçakçısı Ahad, depodaki göçmenler üzerinden ekonomik sermayesini oluşturan, onlar üzerinden her defasında kazanç sağlayan, buna karşın onlara her türlü şiddeti uygulayan, bu anlamda kadınlara tecavüz eden, onları fuhuşa sürükleyen, çocukları ve hastaları ölüme terk eden bir düzen oluşturmuştur. Bu vicdansız ve merhametsiz düzende, Ahad'la birlikte oğlu Gaza'nın da başlangıçta tıpkı babası gibi ama daha sonra kendi başına ve daha ileri teknolojik aygıtları devreye sokarak göçmenler üzerinde tahakküm kurduğu görülmüş̧ür. Gaza'nın, babasıyla birlikte göçmen kaçakçılığını sürdürürken, diğer taraftan da babasının kurmuş olduğu bu çarpık düzenden kaçıp kurtulmaya çalıştığı, ideallerinin peşinden gitmek istediği ve babasının otoritesine boyun eğmediği görülürken, daha sonra Gaza babasının iktidarının son bulmasıyla kendi iktidarını başlatmış ve depodaki kaçak göçmenlerin yeni egemeni halini almıştır. Gaza'nın babasının iktidarına boyun eğdiği ve babasının kurduğu düzenden kaçıp kurtulmaya çalıştı̆ğ dönemde Kandalı Gaza için bir hapishane işlevi görürken, Gaza Kandalı'nın mahkûmu konumunda olmuştur. Gaza'nın babasının iktidarına son verdiği ve kendi iktidarını başlattığı yeni dönemde Kandalı, Gaza için daha önce mahkûmu olduğu hapishanede artık gardiyanı haline geldiği yeni bir mekân olmuştur.

Filmde, göçmen kaçakçılarının gözünden kaçak göçmenler, adeta boş bir hayalin peşinden sürüklenen kişiler olarak görülmüştür. Özellikle göçmen kaçakçısı Ahad'ın bakış açısında Suriyeli göçmenlerin Avrupa'ya göçü, gerçeklerle bağdaşmayan, bu anlamda, gereksiz bir hayalin pençesine düşmüş kişilerin eylemi olarak düşünülmüştür. Ahad, göçmenleri bir böceğe benzetmiş ve onların ezilmeye mahkûm olduklarını vurgulamıştır. Ahad'ın göçmenler hakkındaki söz konusu bakış açısı karşısında Suriyeli göçmenler, umutlarını, hayallerini, arzularını hiçbir zaman yitirmemişlerdir. Öyle ki, kaçak göçmenlerin kaldıkları deponun duvarına kazıdıkları sembollerin göçmenlerin geleceğe ilişkin duygu ve düşüncelerini içerdiği görülmektedir. Semboller vasıtasıyla farklı anlam haritaları oluşturan göçmenler, bu anlamda depoyu bir toplumsal hafıza mekânına dönüştürmüşlerdir. Deponun duvarında yer alan kuş, uçak, el, sandal, otomobil, güneş, ay, çocuklar, ev, ağaç, kayan yıldız, Allah gibi semboller, göçmenlerin geleceğe dair taşıdıkları umutları, sevinçleri, özlemleri, dilekleri, arzuları, beklentileri, aydınlığa çıkışı, özgürlükleri, kurtuluşu vb. anlattığı gibi, aynı zamanda göçmenlerin kimliklerine dair önemli ipuçları oluşturmuştur. Bir toplumsal hafıza mekânı işle- 
vi gören depo, her gelen göçmenin bir iz bıraktığı, kimliğinden bir parçasını sembolize ettiği, kendinden öncekilerin mesajlarına ulaştığı ve kendinden sonrakilere de yeni mesajlar oluşturduğu bir mekân işlevi görmüştür.

Genel olarak incelendiğinde, filmin, baba-oğul arasındaki iktidar mücadelesini, babasının iktidarına karşı direniş ortaya koyan oğulun daha sonra kendi iktidarında giderek babasına dönüşme hikâyesini, Suriyeli kaçak göçmenlerin Türkiye üzerinden Avrupa'ya yolculuklarında yaşadıklarını, karşılaştıkları şiddet, tecavüz, fuhuş ve ölüm gibi durumlarını deneyimleme biçimlerini işlediği görülmüştür. Kandalı olarak bilinen mekân, göçmenlerin depolara hapsedildikleri, daha sonraki süreçte depo içinde depolar oluşturularak yaşam alanlarının daraltıldığı, kamerayla kesintisiz bir şekilde gözetim altına alındıkları, temel ihtiyaçların bile kısıtlı bir şekilde karşılandığı bir mekân olup, bu mekânda egemenler kendi zorbalıklarını keyfi bir biçimde gerçekleştirmişlerdir. Göçmenlerin kaçak göç yollarında insanlıkla bağdaşmayan muamelelere uğramaları, insan haklarının ihlal edilmesi, kadınların, çocukların, hastaların bu süreçten gördüğü zararlar karş1sından göçmenlerin ayakta kalma mücadelelerine devam ettikleri, sonu belli olmayan yoldan geriye dönmeyi bir an olsun düşünmedikleri, çektikleri eziyetlerin onları yollarından alıkoymadıklarını görüyoruz. Umutlarını, hayallerini, dileklerini, arzularını, özlemlerini, özgürlüğe kavuşmalarını, içinde bulundukları karanlıktan bir gün mutlaka kurtulacaklarına olan inançlarını hiç yitirmeyen göçmenlerin göçleri, Türkiye'nin göç deneyimine mutlaka 1şık tutacaktır. 


\section{Kaynakça}

Abadan-Unat, Nermin, Bitmeyen Göç: Konuk İşçilikten Ulus-ötesi Yurttaşll$\breve{g} a$, İstanbul, İstanbul Bilgi Üniversitesi Yayınları, 2006.

Adıgüzel, Yusuf, Göç Sosyolojisi, Ankara, Nobel Akademi Yayınları, 2016.

Alver, Köksal, "Mekân ve Hafıza”, Sosyoloji Divanı, sayı 10, 2017.

Atasü-Topçuoğlu, Reyhan, "Düzensiz Göç: Küreselleşmede Kısıtlanan İnsan Hareketliliği”, Küreselleşme Çağında Göç: Kavramlar, Tartışmalar, der. S. Gülfer Ihlamur-Öner, N. Aslı Şirin-Öner, İstanbul, İletişim Yayınları, 2012.

Aytaç, Ömer, "Mekân(ın) Sosyolojisi: Toplumsalın Yeniden Kuruluşu”, Sosyoloji ve Coğrafya (Sosyoloji Yıllığı - Kitap 15)i yay. haz. Ertan Eğribel, Ufuk Özcan, İstanbul, Kızılelma Yayıncılık, 2006.

Bartram, David - Poros, Maritsa V. - Monforte, Pierre, Göç Meselesinde Temel Kavramlar, çev. Itır Ağabetoğlu Tuncay, Ankara, Hece Yayınları, 2017.

Castles, Stephen - Miller, Mark J., Göçler Çağı: Modern Dünyada Uluslararası Göç Hareketleri, çev. Bülent Uğur Bal, İbrahim Akbulut, İstanbul, İstanbul Bilgi Üniversitesi Yayınları, 2008.

Chambers, Iain, Göç, Kültür, Kimlik, çev. İsmail Türkmen, Mehmet Beşikçi, İstanbul, Ayrıntı Yayınları, 2014.

Coşkun, Emel, "Türkiye'de Göçmen Kadınlar ve Seks Ticareti”, Çalışma ve Toplum, say1 42, 2014.

Çağlayan, Savaş, “Göç Kuramları, Göç ve Göçmen İlişkisi”, Muğla Üniversitesi Sosyal Bilimler Enstitüsü Dergisi, sayı 17, 2006.

Çiçekli, Bülent - Demir, Oğuzhan Ömer, Türkiye Koridorunda Yasadışı Göçmenler, Ankara, Karınca Yayınları, 2013.

Erbaş, Hayriye, Göç ve Göçmenler: Kuram, Yöntem ve Alan Yazılarl, Ankara, Phoenix Yayınları, 2019.

Erder, Sema, "Yabancısız Kurgulanan Ülkenin Yabanc1ları”, Türkiye'de Yabancı Iş̧̧iler: Uluslararası Göç, Isşgücü ve Nüfus Hareketleri, der. F. Aylan Arı, İstanbul, Derin Yayınları, 2007.

Erder, Sema, İstanbul Bir Kervansaray (mı?): Göç Yazıları, der. Nesrin Uçarlar, İstanbul, İstanbul Bilgi Üniversitesi Yayınları, 2015.

Fromm, Eric, Rüyalar, Masallar, Mitoslar, çev. Aydın Arıtan, Kaan H. Ökten, İstanbul, Arıtan Yayınevi Yayınları, 1992. 
Halbwachs, Maurice, Hafizanın Toplumsal Çerçeveleri, çev. Büşra Uçar, Ankara, Heretik Yayınları, 2016.

Harvey, David, Sosyal Adalet ve Şehir, çev. Mehmet Moral1, İstanbul, Metis Yayınlar1, 2003.

İçduygu, Ahmet, Türkiye'de Kaçak Göç, İstanbul, İstanbul Ticaret Odası Yayınları, 2004.

İlhan, M. Emir, Kültürel Bellek: Sözlü Kültürden Yazılı Kültüre Hatırlama, Ankara, Doğu Batı Yayınları, 2018.

Jung, Carl Gustav, Insan ve Sembolleri, çev. Ali Nahit Babaoğlu, İstanbul, Okyanus Yayınları, 2009.

Lefebvre, Henri, Mekânın Üretimi, çev. Işık Ergüden, İstanbul, Sel Yayınları, 2015.

Özdemir, Özlem, “Geçmişe Mazi Diyebildik mi? Bir Bellek Mekânı Olarak Sinema", Neye Yarar Hatıralar? Bellek ve Siyaset Çalışmaları, der. Pınar Melis Yelsalı Parmaksız, Ankara, Phoenix Yayınları, 2012.

Özer, Elif, Kimse Duymaz: Türkiye'de İnsan Ticareti Mağdurları Üzerine Bir Araştırma, Ankara, Ayizi Yayınları, 2012.

Pekerman, Serazer, Film Dilinde Mahrem: Ulusötesi Sinemada Kadın ve Mekân Temsili, İstanbul, Metis Yayınları, 2012.

Peköz, Mustafa, Küresel Kapitalizm ve Göçmenlik, İstanbul, Karakoyun Yayınları, 2012.

Toksöz, Gülay, Uluslararası Emek Göçü, İstanbul, İstanbul Bilgi Üniversitesi Yayınları, 2006.

Yalçın, Cemal, Göç Sosyolojisi, Ankara, Anı Yayınları, 2004. 